\title{
The molecular biology of pelvi-ureteric junction obstruction
}

\author{
Laura Jackson $^{1,2}$ (D) $\cdot$ Mark Woodward ${ }^{2} \cdot$ Richard J. Coward ${ }^{1,2}$
}

Received: 11 October 2016 /Revised: 16 February 2017 / Accepted: 17 February 2017 /Published online: 13 March 2017

(C) The Author(s) 2017. This article is published with open access at Springerlink.com

\begin{abstract}
Over recent years routine ultrasound scanning has identified increasing numbers of neonates as having hydronephrosis and pelvi-ureteric junction obstruction (PUJO). This patient group presents a diagnostic and management challenge for paediatric nephrologists and urologists. In this review we consider the known molecular mechanisms underpinning PUJO and review the potential of utilising this information to develop novel therapeutics and diagnostic biomarkers to improve the care of children with this disorder.
\end{abstract}

Keywords Pelvi-ureteric junction obstruction · Aetiology · Molecular biology $\cdot$ Biomarker $\cdot$ Hydronephrosis

\section{Introduction}

Antenatally detected hydronephrosis is a major clinical dilemma for paediatric nephrologists and urologists (incidence of 1 in 200) [1]. This condition has become more prevalent in recent years as antenatal scanning has become more sensitive and widely used. Approximately one in seven neonates with antenatally detected hydronephrosis has pelvi-ureteric junction obstruction (PUJO) [2-4], making PUJO one of the most common causes of congenital urinary tract obstruction, with

Laura Jackson

laura.jackson@bristol.ac.uk

1 Bristol Renal Group, University of Bristol, Dorothy Hodgkin Building, Whitson Street, Bristol BS1 3NY, UK

2 Bristol Royal Hospital for Children, Bristol, UK an incidence of one in 1000 to one in 2000 live births [3-5]. Interestingly, males are affected approximately threefold more frequently than females by this condition [4]. The reason for this difference is unknown.

Intrinsic obstruction due to an adynamic stenotic segment at the PUJ is the most common aetiology (75\% of cases) [4], with failure of peristalsis producing an incomplete, functional obstruction. Other causes include: crossing vessels (20\%), peripelvic fibrosis, abnormal ureteric insertion, fibroepithelial polyps and anatomical variants, such as retrocaval ureter, horseshoe and duplex kidneys [4, 6, 7].

The major challenge for clinicians is deciding which of these children, who are largely asymptomatic, require a pyeloplasty to relieve the obstruction. This is because twothirds of children with PUJO do not sustain renal damage or need surgery, and their hydronephrosis spontaneously improves [8-10].

Currently, serial ultrasound and invasive isotope studies are performed to guide surgical management of PUJO [4]. However, the ability of these diagnostic modalities to accurately detect obstruction, identify children at risk of functional deterioration and predict the need for surgery is questionable. Additionally, there remains debate regarding the parameters which indicate clinically significant obstruction $[9,11-13]$.

In general a pyeloplasty is performed for [6]:

- differential renal function deterioration (differential function of $<40 \%$ or a fall of $>10 \%$ on serial MAG3 renograms)

- significant hydronephrosis with a renal pelvis anteroposterior diameter of $>3 \mathrm{~cm}$ on ultrasound scan

- increasing hydronephrosis with an increasing anteroposterior diameter on serial ultrasound scan

- symptomatic children. 
Our current understanding of the natural history of PUJO as well as our ability to distinguish which children require surgery is inadequate. Available diagnostic tests cannot accurately discern between children with PUJO that will resolve spontaneously and those with PUJO that will persist, causing functional impairment. Consequently, despite radiological monitoring, there is a risk of loss of function in the affected kidney while the patient is under observation [14].

In this review we discuss the currently known molecular mechanisms underlying intrinsic PUJO and whether this information could contribute to the future development of novel therapies and diagnostic biomarkers.

\section{Anatomy of the upper urinary tract}

The PUJ is a region of gradual transition from the funnelshaped renal pelvis to the proximal ureter [15] (Fig. 1). It is a physiologic sphincter [16] that is characterised by prominent luminal folds with increased muscle thickness capable of creating a high-pressure zone to regulate urine flow. Similar to the adjacent renal pelvis and ureter, the PUJ comprises three main layers: the inner urothelium, middle smooth muscle and outer adventitia [15]. Smooth muscle contraction propels urine from the renal pelvis to the bladder [17], coordinated by submucosal and intra-muscular nerve plexi [18] and modulated by autonomic innervation involving a range of neurotransmitters that include acetylcholine, noradrenaline, substance $\mathrm{P}$, neurokinin A, calcitonin gene-related peptide, neuropeptide $\mathrm{Y}$, vasoactive intestinal peptide and nitric oxide (NO) [17].

\section{Embryology of the ureter and PUJ}

Understanding the normal embryology of PUJ formation is vital when considering where development may proceed incorrectly in congenital abnormalities such as PUJO. The kidney develops from metanephric mesoderm as far along the nephron as the distal tubules. The collecting duct onwards, including the major and minor calyces, renal pelvis and ureter has a different embryological origin, arising from the ureteric bud [19, 20]. Thus, the PUJ does not represent an embryological fusion site, rather it is derived exclusively from the ureteric bud. The important molecular pathways that form the ureter and PUJ are shown in Fig. 2 and Table 1 [15, 26-28]. Briefly, the ureteric bud, consisting of a simple epithelial layer extending into loose mesenchyme, arises from the mesonephric duct during the fifth week of gestation in humans [26]. Epithelial cell proliferation and differentiation then results in the formation of the transitional epithelium. Epithelial paracrine and mesenchymal autocrine signalling stimulates the formation of smooth muscle cells from mesenchyme, which begins at 12 weeks of gestation in humans [26, 29]. Mouse models have implicated a number of signalling molecules in this process of proliferation, aggregation, differentiation and orientation of smooth muscle cells as they encircle the urothelial tube (Fig. 2, Table 1). A second phase of smooth muscle differentiation that particularly affects the renal pelvis and proximal ureter occurs in postnatal mice (equivalent to the second trimester of gestation in humans) and is regulated by calcineurin and angiotensin II signalling $[30,31]$.
Fig. 1 Diagrammatic representation of the pelviureteric junction (PUJ). The gradual transition from the renal pelvis to the proximal ureter is illustrated as well as the increased mucosal folds and smooth muscle thickening in this region

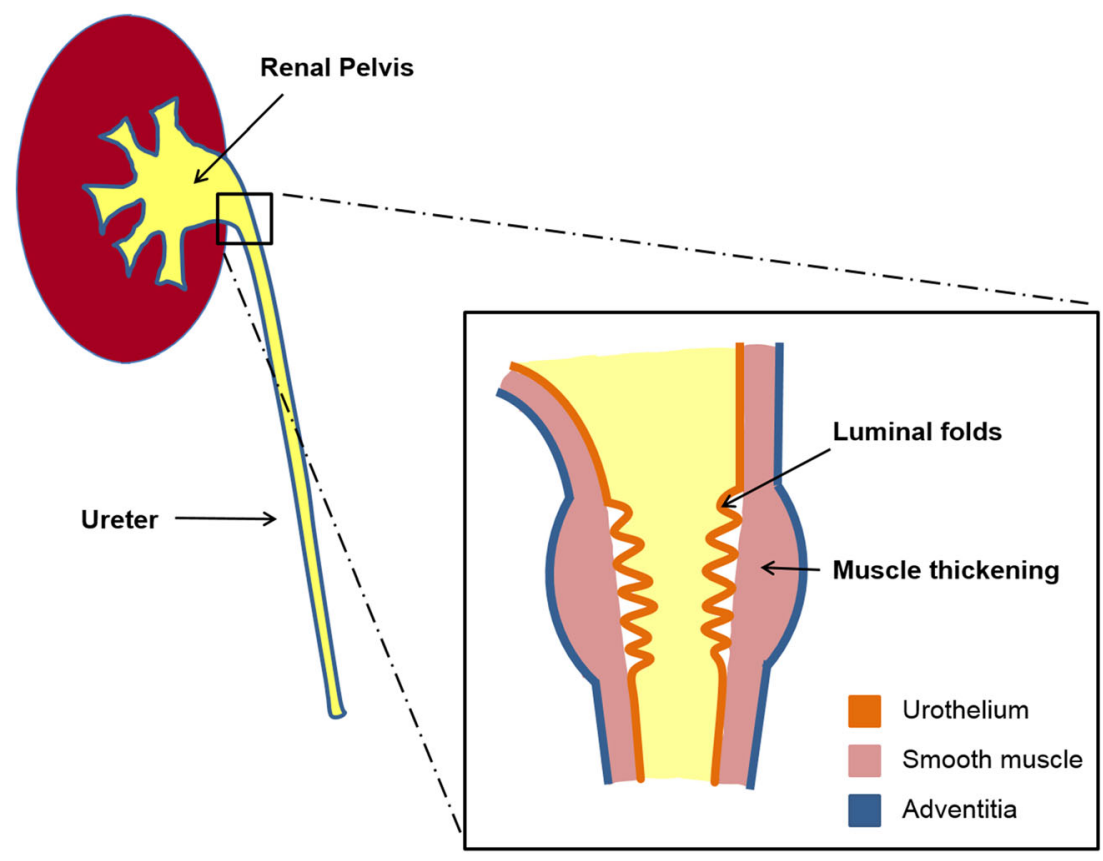

Pelvi-ureteric junction 


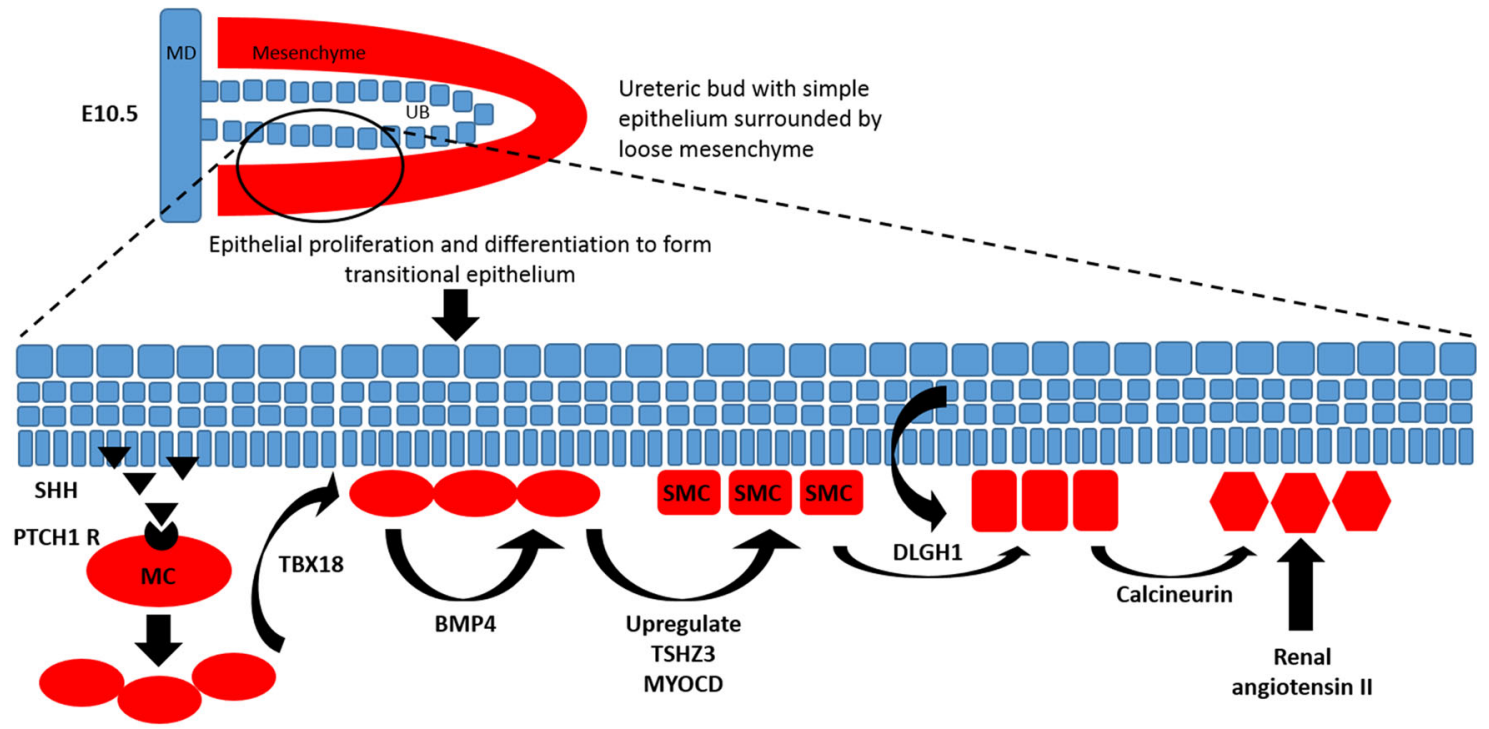

Proliferation

Aggregation

Differentiation

Orientation

Further differentiation

at renal

pelvis/proximal ureter

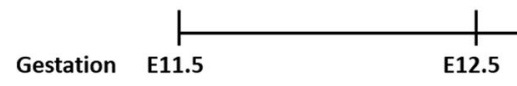

Fig. 2 Embryological signalling pathways of the PUJ. The ureteric bud arises from the mesonephric duct and initially consists of only a simple epithelial layer extending into loose mesenchyme. Epithelial cell proliferation and differentiation to form transitional epithelium leads to luminal obliteration, which at the end of the embryonic period is corrected by physiologic recanalisation of the ureter. Epithelial paracrine and mesenchymal autocrine signalling stimulates the proliferation and differentiation of the mesenchyme into smooth muscle cells $(S M C)$ which aggregate and orientate so as to encircle the epithelial tube. Specifically, the urothelium secretes SHH which activates the PTCH1 receptor on adjacent mesenchyme, thereby stimulating mesenchymal proliferation. Mesenchymal cells $(M C)$ express TBX18, a T-box transcription factor, which enables the correct localisation and aggregation of the former around the urothelium. The mesenchymal cells also

\section{Pathologic features of intrinsic PUJO}

Inflammatory cell infiltration [32], varying degrees of fibrosis, excess collagen deposition [32-35] and abnormal muscle fibre arrangement [36] are present in human intrinsic PUJ obstruction. Both muscular hypertrophy/ hyperplasia [32, 34, 37] and atrophy/hypoplasia [32, 36] are reported alongside depletion of nerves to the muscular layer [33]. These findings are noted when the PUJ is excised at pyeloplasty and therefore represent late features of PUJ obstruction (Fig. 3). Although the time course of PUJ disease progression is unknown in humans, genetic mouse models of hydronephrosis show abnormalities of peri-urothelial mesenchymal organisation as early as embryonic day (E) 12.5 (approximately equivalent to 35 days of gestation in humans) [24] and smooth muscle cell differentiation at E15.5 (approximately equivalent to 12 weeks of gestation in humans)

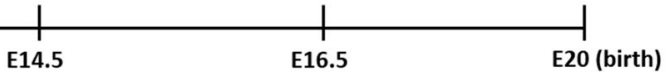

express BMP4 which acts in an autocrine manner to upregulate TSHZ3 and MYODC. MYODC enables differentiation of SMC by increasing the transcription of genes encoding smooth muscle contractile proteins. DLGH1, expressed by the urothelium and SMC, is responsible for the correct orientation of SMC around the urothelial tube. In postnatal mice (equivalent to second trimester of gestation in humans), increased urine production matches the development of the renal pelvis and is accompanied by a second phase of muscle differentiation that particularly affects the renal pelvis and proximal ureter, regulated by calcineurin and angiotensin II signalling. The timeline refers to days of gestation ( $E$ embryonic day) in mouse models. $M D$ Mesonephric duct, $U B$ ureteric bud, $M C$ mesenchymal cells. See Table 1 for description of factors active in the pathways involved in ureteric development

[23]. One week postnatally (approximately equivalent to humans at birth) mice with Id2 haploinsufficiency show smooth muscle irregularity and hypertrophy at the PUJ [38], features which are common to human PUJO. The possible mechanisms underlying this pathology are described later in this review.

\section{Modelling PUJO to understand its molecular biology}

Adult and neonatal rodent models of complete and partial unilateral ureteric obstruction (UUO) have been extensively used to investigate the molecular biology of congenital obstructive nephropathy. Neonatal models are particularly helpful because rodent nephrogenesis continues for 1 week postnatally and nephron maturation over the subsequent week. Thus, at birth and 1 week of age, rodent kidney development is equivalent to humans at the second 
Table 1 Proteins/molecular pathways involved in ureteric development

\begin{tabular}{|c|c|c|c|}
\hline Protein & Full protein name & Function & Reference \\
\hline $\mathrm{SHH}$ & Sonic hedgehog & $\begin{array}{l}\text { Morphogen which stimulates } \\
\text { peri-urothelial mesenchymal cell pro- } \\
\text { liferation and regulates timing of } \\
\text { smooth muscle cell differentiation }\end{array}$ & {$[21]$} \\
\hline PTCH1 receptor & Protein patched homolog 1 & $\begin{array}{l}\text { Receptor for SHH, functions as tumour } \\
\text { suppressor when unbound }\end{array}$ & {$[21]$} \\
\hline BMP4 & Bone morphogenetic protein 4 & $\begin{array}{l}\text { Growth factor, necessary for smooth } \\
\text { muscle cell differentiation and ureter } \\
\text { morphogenesis }\end{array}$ & {$[22]$} \\
\hline TSHZ3 & Teashirt zinc finger homeobox 3 & $\begin{array}{l}\text { Transcription factor-like protein neces- } \\
\text { sary for myocardin expression and } \\
\text { ureteric smooth muscle cell differenti- } \\
\text { ation }\end{array}$ & {$[23]$} \\
\hline MYOCD & Myocardin & $\begin{array}{l}\text { Transcriptional co-activator, necessary } \\
\text { for expression of contractile proteins }\end{array}$ & {$[23]$} \\
\hline TBX18 & T Box protein 18 & $\begin{array}{l}\text { Transcription factor necessary for correct } \\
\text { localisation and aggregation of smooth } \\
\text { muscle cells around ureteric } \\
\text { urothelium }\end{array}$ & {$[24]$} \\
\hline DLGH1 & Disks large homolog 1 & $\begin{array}{l}\text { Scaffolding protein, regulates smooth } \\
\text { muscle cell orientation }\end{array}$ & {$[25]$} \\
\hline
\end{tabular}

trimester of gestation and birth, respectively [11]. This gives a window in which surgery can be performed on the animals to mimic in utero obstruction in humans. Adult obstructive models show a broadly similar pathologic progression to neonatal models with the exception that neonatal obstruction impedes normal maturation and growth of the kidney and leads to early nephron loss. The renal pathologic findings in neonatal and adult UUO models and the timescale of their development are presented in Fig. 4 [39-47].

A comprehensive review comparing neonatal models with human disease confirms their validity for investigating obstructive nephropathy and will not be further discussed in this review [48].

\section{Proposed molecular mechanisms underpinning PUJO}

In the following subsections we highlight some of the molecular steps that may lead to the development of intrinsic PUJO and subsequent obstructive nephropathy. Data have been obtained from both adult and neonatal models of complete and partial ureteric obstruction alongside evaluation of tissue obtained at pyeloplasty for human PUJ obstruction.

\section{Neurogenic factors}

Light microscopy studies have revealed reduced innervation within the muscular layer of the PUJ in human specimens
Fig. 3 Pathologic features of intrinsic PUJO. Reduced luminal mucosal folds, excess collagen deposition, depletion of nerves within the muscular layer, abnormal muscle fibre arrangement, inflammatory infiltrate and both muscle hypertrophy/hyperplasia and muscle atrophy/hypoplasia are seen at the PUJ in human PUJO

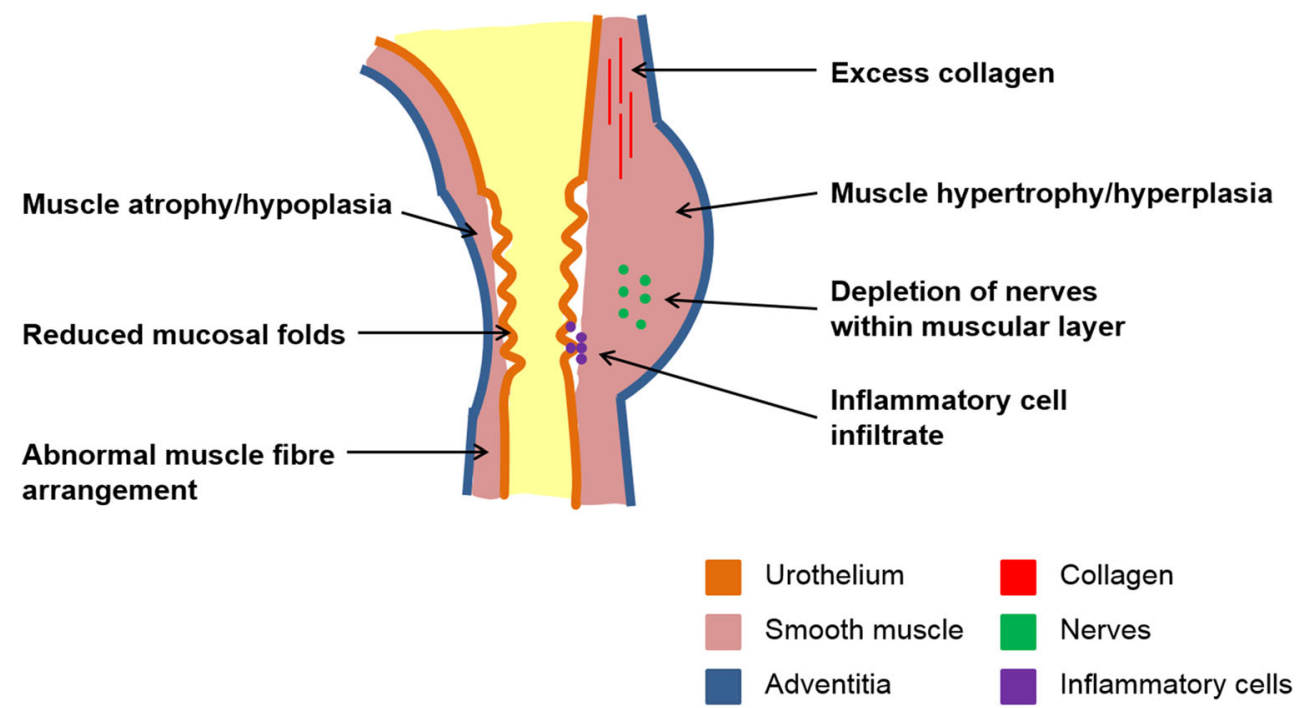


Fig. 4 Pathologic features of rodent models of unilateral ureteric obstruction $(U U O)$.

Timeline of the development of renal pathogenic features in neonatal and adult models of UUO. CUUO Complete UUO, PUUO partial UUO

\section{Days after UUO}

1

2

3

4

5

7

14

15-28

21-42 excised at pyeloplasty for PUJO [33]. This is associated with reduced expression of molecular markers, including glial cell line-derived neurotrophic factor (survival factor for neurons), protein gene product 9.5 (general neuronal marker), and nerve growth factor receptor protein, in the muscle layers of the stenotic PUJ compared to controls. Although it is speculated that these neuronal changes may contribute to the

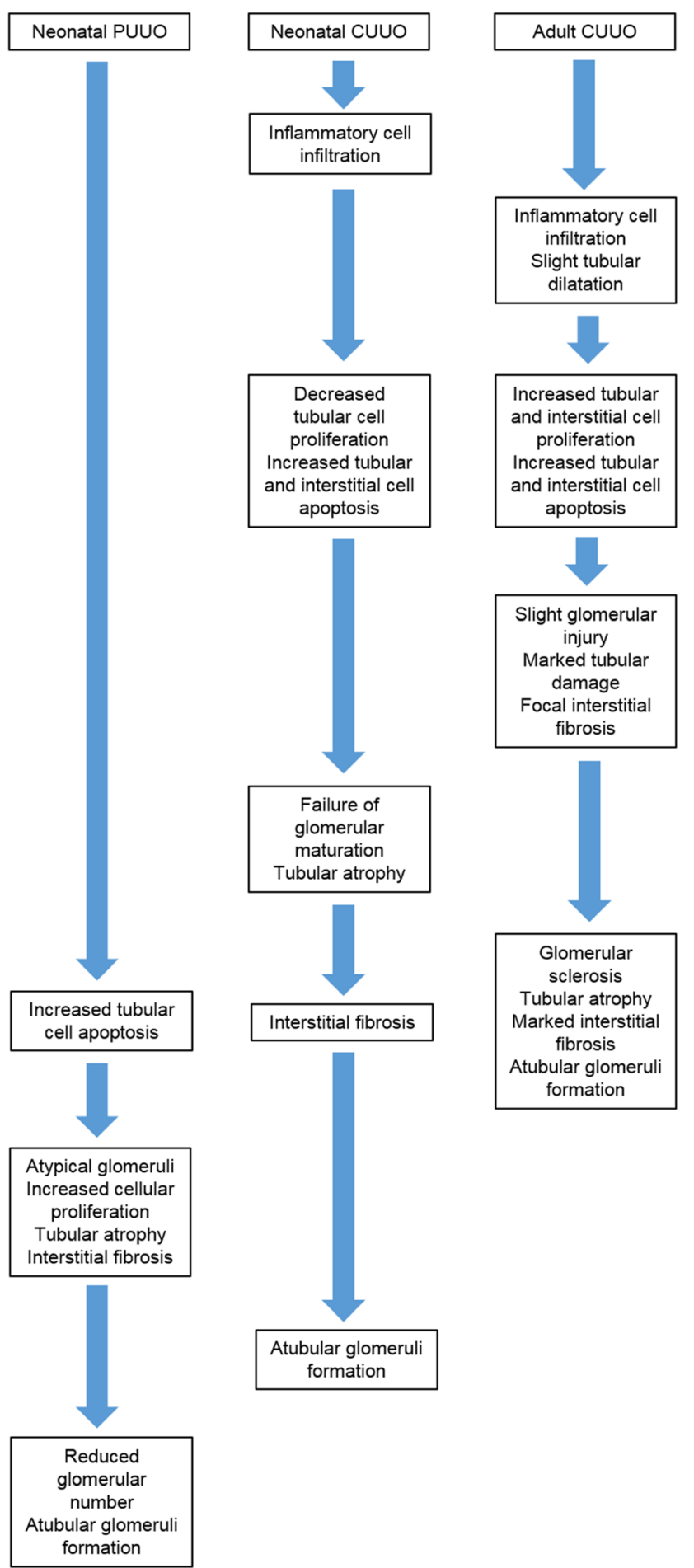

pathogenesis of PUJO, there is as yet no evidence to confirm or refute this notion. Conflicting changes in synaptophysin (e.g. major synaptic vesicle protein p38) expression in terms of both amount (increased and decreased) and distribution (localisation to the nucleus) are reported in PUJO compared to controls and are of uncertain significance. S-100 (schwann cell marker) and neurofilament (neuronal protein) expression 
are unchanged, demonstrating there is not a global reduction in neuronal components $[34,49]$.

\section{Myogenic factors}

Together with increased smooth muscle cell apoptosis, phenotypic and cytoskeletal smooth muscle cell changes are seen in the human PUJ excised at pyeloplasty for PUJO. The stenotic PUJ shows significantly increased expression of smooth muscle myosin heavy chain isoforms 1 and 2 [37], as well as an altered ratio of integrin (transmembrane signalling receptor) isoform expression compared to control samples [50]. The preferential expression of immature integrins in the stenotic PUJ [50] may indicate developmental delay of the smooth muscle cells, potentially contributing to their altered function and increased apoptosis in PUJO.

Supporting a myogenic cause of PUJO, transgenic mouse models targeting smooth muscle differentiation generate a PUJ phenotype with hydronephrosis secondary to functional obstruction (Table 2).

Table 2 Evidence from animal and human studies of genes potentially involved in the pathogenesis of pelvi-ureteric junction obstruction

\begin{tabular}{|c|c|c|c|c|c|}
\hline Gene & Full gene name & Animal & Features and mechanism & Human & Reference \\
\hline Ace & $\begin{array}{l}\text { Angiotensin converting } \\
\text { enzyme }\end{array}$ & $\mathrm{Ace}^{-/-}$mice & $\begin{array}{l}\text { Hydronephrosis, renal } \\
\text { parenchymal atrophy }\end{array}$ & & {$[51]$} \\
\hline Adamts-1 & $\begin{array}{l}\text { A disintegrin-like and } \\
\text { metallopeptidase with } \\
\text { thrombospondin type } 1 \\
\text { motif, } 1\end{array}$ & $\begin{array}{l}\text { Adamts }^{-1-/-} \\
\text { mice }\end{array}$ & $\begin{array}{l}\text { PUJ obstruction, increased } \\
\text { collagen at PUJ. Other } \\
\text { urogenital anomalies. }\end{array}$ & & {$[52]$} \\
\hline Agt & Angiotensin & $A g t^{-/-}$mice & $\begin{array}{l}\text { Hydronephrosis, renal } \\
\text { parenchymal atrophy, }\end{array}$ & & {$[53]$} \\
\hline Agtr $1 a / b$ & $\begin{array}{l}\text { Angiotensin II receptor type } 1 \\
\quad \text { (1a and } 1 \mathrm{~b})\end{array}$ & $\begin{array}{l}A g t r 1^{-1-}(1 a \text { and } \\
1 b) \text { mice }\end{array}$ & $\begin{array}{l}\text { Hydronephrosis in older mice, } \\
\text { renal parenchymal atrophy, } \\
\text { failure of renal pelvis } \\
\text { development, ureteric } \\
\text { smooth muscle hypoplasia } \\
\text { and abnormal peristalsis }\end{array}$ & & {$[31]$} \\
\hline Aqp 2 & Aquaporin 2 & $\begin{array}{c}A q p^{2 \mathrm{~S} 256 \mathrm{~L} / \mathrm{S} 256 \mathrm{~L}} \\
\mathrm{CPH} \text { mice }\end{array}$ & $\begin{array}{l}\text { Mutation in CPH mice } \\
\text { prevents Aqp2 } \\
\text { phosphorylation and } \\
\text { normal trafficking. } \\
\text { Hydronephrosis secondary } \\
\text { to polyuria }\end{array}$ & & {$[54]$} \\
\hline Calcineurin & $\begin{array}{l}\text { Calcineurin. Also known as } \\
\text { Protein phosphatase } 3 \\
\text { (ppp3) }\end{array}$ & $\begin{array}{l}\text { Pax3-Cre } e^{\mathrm{T} /+} ; \\
\quad C n b 1^{\text {flox/ flox }} \\
\text { mice }\end{array}$ & $\begin{array}{l}\text { Calcineurin inactivation in } \\
\text { metanephric and ureteral } \\
\text { mesenchyme giving } \\
\text { hydronephrosis, abnormal } \\
\text { pyeloureteral peristalsis } \\
\text { with defective renal pelvis } \\
\text { and smooth muscle } \\
\text { development }\end{array}$ & & {$[30]$} \\
\hline$I d 2$ & Inhibitor of DNA binding 2 & $\begin{array}{l}I d 2^{-/-} \text {and } I d 2 \\
+/- \\
\text { mice }\end{array}$ & $\begin{array}{l}\text { Hydronephrosis and PUJ } \\
\text { development }\end{array}$ & & {$[38]$} \\
\hline Nfia & Nuclear factor I/A & $\begin{array}{l}\mathrm{Nfia}^{+/-} \text {and } \\
\mathrm{Nfia}^{-/-} \text {mice }\end{array}$ & $\begin{array}{l}\text { Hydroureteronephrosis, VUR, } \\
\text { abnormal PUJ and VUJ } \\
\text { development. CNS } \\
\text { malformations. }\end{array}$ & $\begin{array}{l}\mathrm{Nfia}^{+/-} \text {due to chromosomal } \\
\text { translocation and deletion. } \\
\text { VUR and CNS } \\
\text { malformations. }\end{array}$ & {$[55]$} \\
\hline$T B X 18$ & T-box transcription factor & $\operatorname{Tb} \times 18^{-/-}$mice & $\begin{array}{l}\text { Hydroureteronephrosis, short } \\
\text { ureters, ureteric smooth } \\
\text { muscle defects due to } \\
\text { abnormal smooth muscle } \\
\text { cell differentiation and } \\
\text { localisation }\end{array}$ & $\begin{array}{l}\text { Hispanic family with } \\
\text { autosomal dominant } \\
\text { CAKUT predominantly } \\
\text { PUJO. Heterozygous } \\
\text { truncating mutation } \\
\text { (c.1010delG) of } T b x 18\end{array}$ & {$[24,56]$} \\
\hline$T s h z 2$ and 3 & $\begin{array}{l}\text { Teashirt zinc finger family } \\
\text { member } 2 \text { and } 3\end{array}$ & $T s h z 3^{-1-}$ mice & $\begin{array}{l}\text { Hydronephrosis with PUJ } \\
\text { configuration, abnormal } \\
\text { smooth muscle } \\
\text { differentiation proximal } \\
\text { ureter }\end{array}$ & $\begin{array}{l}\text { Tshz2/Tshz3 mutations not } \\
\text { cause of PUJO in } \\
\text { Albanian/Macedonian } \\
\text { population }\end{array}$ & {$[57,58]$} \\
\hline
\end{tabular}

CAKUT, Congenital anomalies of the kidney and urinary tract; CNS, central nervous system; $\mathrm{CPH}$, congenital progressive hydronephrosis; PUJO, pelviureteric junction obstruction; VUJ, vesico-ureteric junction; VUR, vesico-ureteric reflux 


\section{Increased pressure, impeded blood supply and hypoxia}

Obstructive hydronephrosis is associated with a doubling to trebling of renal pelvis pressure [16, 59-61]. The resultant increased intratubular hydrostatic pressure [62] stimulates the renopathogenic effects of obstruction via three proposed mechanisms, namely, (1) tubular ischaemia due to hypoperfusion, (2) pressure-induced mechanical stretch/compression of tubular cells and (3) altered urinary shear stress. The latter two mechanisms are likely to be the primary inducers of obstructive renal injury [48], causing dysregulation of many cytokines, growth factors, enzymes and cytoskeletal proteins (Table 3), resulting in early renal haemodynamic changes followed by structural and functional alterations to the entire nephron. Figure 5 highlights the major mechanisms of renal injury in PUJO.

Following a short initial increase in renal blood flow related to local vasodilator production [48], the intrarenal renin-angiotensin-aldosterone system (RAAS) is activated causing pre- and post-glomerular vasoconstriction and a resultant fall in renal blood flow (RBF), medullary oxygen tension and glomerular filtration rate (GFR) [11, 48, 64, 80, 88-90]. Proximal tubular hypoxia and necrosis in neonatal rats with UUO suggest that vasoconstriction causes segment-specific ischaemic injury [91]. Accordingly, angiotensin II receptor, type 1 (AT1 receptor) inhibition improves tubular function by increasing $\mathrm{RBF}$ and GFR [92].

Reduced urine production and continuing urine drainage by venous and lymphatic systems together with tubular and renal pelvis dilatation result in a subsequent decline in renal pelvic pressure [48, 89, 93], which may be a compensatory mechanism to limit damaging increased intra-renal pressure [93].

\section{Initiation of proinflammatory cytokines}

\section{Cytokines in the stenotic PUJ}

Transforming growth factor-beta (TGF- $\beta$ ) expression is noted in human stenotic PUJ compared to normal controls [94]. Furthermore, the smooth muscle regulators endothelin-1 (smooth muscle constrictor) and adrenomedullin (smooth muscle relaxant) have been shown to be increased and decreased, respectively, in stenotic PUJ disease [95].

Analysis of paediatric renal pelvis tissue proximal to the PUJO for cytokines that show altered renal expression in nephropathy demonstrates increased TGF- $\beta$ and reduced macrophage inflammatory protein-1alpha (MIP-1 $\alpha)$. In contrast, epidermal growth factor (EGF), monocyte chemotactic peptide 1 , interferon- $\gamma$-inducible protein 10 and RANTES (regulated on activation normal T-cell expressed and secreted) mRNA expression are unchanged, suggesting that TGF- $\beta$ and MIP- $1 \alpha$ play important roles in the development of PUJO $[88,96]$.

\section{Intra-renal cytokines}

Increased intra-renal angiotensin II activates nuclear factor kappa B and ROCK (rho-associated coiled-coil-forming protein kinase), leading to cytokine release and interstitial macrophage infiltration and activation. Intra-renal selectins, integrins, intercellular-adhesion molecule 1 , vascular cell adhesion molecule 1 , interleukin 1 , monocyte chemoattractant peptide 1 , colony stimulating factor 1 and osteopontin expression are all involved in macrophage stimulation [11, 48, 88, 97]. Therefore, it appears that renal signals initiate and maintain the injurious inflammatory response to PUJO. Accordingly, both selectin and $\beta 2$-integrin knockout mouse models show reduced macrophage infiltration into the obstructed kidney after UUO [43, 44].

\section{Inflammatory infiltrates}

Activated macrophages infiltrate the renal interstitium, sustaining the inflammatory response by releasing cytokines, such as TGF- $\beta 1$, tumour necrosis factor-alpha (TNF- $\alpha$ ), and platelet-derived growth factor $[11,88]$.

\section{Profibrotic processes}

Tubulointerstitial fibrosis is the final common pathway for many chronic kidney disorders, including obstructive uropathy, and is instigated by altered cytokine expression (Table 4). Activated resident interstitial myofibroblasts [98], expressing $\alpha$-smooth muscle actin (boosts cell contractility) [99], aggregate, proliferate and produce extracellular matrix. Extracellular matrix consisting of collagens I, III and IV, fibronectin, laminin and proteoglycans accumulates due to increased synthesis and reduced degradation $[74,100,101]$. Myofibroblasts amplify fibrosis by producing cytokines, including TGF- $\beta 1$ and TNF- $\alpha$ [11]. Parenchymal damage and renal dysfunction results, such that in children with PUJO the extent of fibrosis significantly correlates with differential renal function [102].

Angiotensin II upregulation is central to the pathogenesis of obstructive nephropathy (Fig. 6) [11, 41, 45, 64, 68, 83, 84, 91, 103-112]. Angiotensinogen murine knockout studies have demonstrated that angiotensin II expression is responsible for at least $50 \%$ of renal fibrosis in chronic neonatal UUO [104]. Acting predominantly via the AT1 receptor $[45,105,113]$ it regulates cytokine production and stimulates reactive oxygen species (ROS) generation, which in turn propagates the proinflammatory, fibrogenic state [48, 104]. The generation of ROS also causes proximal tubular degeneration by apoptosis, autophagy and necrosis, with consequent destruction of 
Table 3 Table showing the major cytokines, growth factors, chemokines, enzymes and cytoskeletal proteins which demonstrate altered intra-renal regulation in obstructive nephropathy, the timing of these changes and their mode of action

\begin{tabular}{|c|c|c|c|c|}
\hline Protein $^{\mathrm{a}}$ & Action & Change/timing & Species & Reference \\
\hline Angiotensin II & $\begin{array}{l}\text { Vasoregulatory, } \\
\text { proinflammatory, } \\
\text { proapoptotic, profibrotic }\end{array}$ & $\begin{array}{l}\text { Increased } 28 \text { days } \\
\text { Increased } 1 \text { week and } 5 \text { weeks } \\
\text { Increased after mechanical stretch }\end{array}$ & $\begin{array}{l}\text { Neonatal rat CUUO } \\
\text { Adult rat CUUO } \\
\text { In vitro podocytes }\end{array}$ & $\begin{array}{l}{[63]} \\
{[64]} \\
{[65]}\end{array}$ \\
\hline$\alpha$-SMA & $\begin{array}{l}\text { Increases myofibroblast } \\
\text { contractility/EMT marker }\end{array}$ & $\begin{array}{l}\text { Increased } 5 \text { days } \\
\text { Increased } 4 \text { days }\end{array}$ & $\begin{array}{l}\text { Neonatal rat CUUO } \\
\text { Adult mouse CUUO }\end{array}$ & $\begin{array}{l}{[39]} \\
{[66]}\end{array}$ \\
\hline Caspases & Proapoptotic & $\begin{array}{l}\text { Increased } 14 \text { days } \\
\text { Increased } 1 \text { day }\end{array}$ & $\begin{array}{l}\text { Neonatal rat CUUO } \\
\text { Adult rat CUUO }\end{array}$ & $\begin{array}{l}{[67]} \\
{[68]}\end{array}$ \\
\hline Clusterin & $\begin{array}{l}\text { Cytoprotective via } \\
\text { pro-survival autophagy }\end{array}$ & Increased 5 days & Neonatal rat CUUO & [39] \\
\hline $\mathrm{COX}-2$ & $\begin{array}{l}\text { Polyuria and natriuresis, } \\
\text { anti-apoptotic, antifibrotic }\end{array}$ & $\begin{array}{l}\text { Increased } 24 \mathrm{~h} \\
\text { Increased } 3 \text { days (mRNA) }\end{array}$ & $\begin{array}{l}\text { Adult rat CBUO } \\
\text { Adult mouse CUUO }\end{array}$ & $\begin{array}{l}{[69]} \\
{[70]}\end{array}$ \\
\hline CTGF & Profibrotic & Increased 2 days (mRNA) & Adult rat CUUO & {$[45]$} \\
\hline EGF & Epithelial survival factor & $\begin{array}{l}\text { Decreased } 7 \text { days (mRNA) (Undetectable } \\
\text { expression in neonatal rat kidney before } \\
4 \text { days) } \\
\text { Decreased } 33 \text { days } \\
\text { Decreased at pyeloplasty (mean age } 2 \text { years) } \\
\quad \text { (mRNA) } \\
\text { Decreased at pyeloplasty (mean age } 5 \text { years) }\end{array}$ & $\begin{array}{l}\text { Neonatal rat both CUUO and } \\
5 \text { day CUUO then release } \\
\text { Human renal biopsy } \\
\text { Human renal biopsy }\end{array}$ & $\begin{array}{l}{[71]} \\
{[39]} \\
{[72]} \\
{[73]}\end{array}$ \\
\hline ET-1 & Vasoconstrictor & Increased 2 days (mRNA) & Adult rat CUUO & {$[45]$} \\
\hline Fas-L & Proapoptotic & Increased 1 day (mRNA) & Adult rat CUUO & {$[68]$} \\
\hline HSP-70 & Antiapoptotic & Decreased 14 days & Neonatal CUUO & {$[67]$} \\
\hline ICAM-1 & Proinflammatory & Increased 3 days & Adult mouse CUUO & {$[74]$} \\
\hline Il-6 & Proinflammatory & Increased 2 days (mRNA) & Adult rat CUUO & {$[45]$} \\
\hline Integrin $(\beta 1)$ & Profibrotic & $\begin{array}{l}\text { Increased } 3 \text { days } \\
\text { Increased after mechanical stretch }\end{array}$ & $\begin{array}{l}\text { Adult mouse CUUO } \\
\text { In vitro proximal tubular cells }\end{array}$ & $\begin{array}{l}{[75]} \\
{[76]}\end{array}$ \\
\hline MCP-1 & Proinflammatory & $\begin{array}{l}\text { Increased } 12 \text { days, no change } 4 \text { days } \\
\text { Increased } 2 \text { days (mRNA) } \\
\text { Increased at pyeloplasty (mean age } 2 \text { years) } \\
\quad \text { (mRNA) }\end{array}$ & $\begin{array}{l}\text { Neonatal rat CUUO } \\
\text { Adult rat CUUO } \\
\text { Human renal biopsy }\end{array}$ & $\begin{array}{l}{[77]} \\
{[45]} \\
{[72]}\end{array}$ \\
\hline MMP 2 and 9 & ECM degradation & Decreased 3 days & Adult mouse CUUO & {$[74]$} \\
\hline PAI-1 & $\begin{array}{l}\text { Profibrotic, inhibits ECM } \\
\text { degradation }\end{array}$ & Increased 7 days & Adult mouse CUUO & [78] \\
\hline PDGF & Profibrotic & Increased 4 days & Adult mouse CUUO & {$[66]$} \\
\hline NF-kB & Regulatory transcription factor & Increased 2 days & Adult mouse CUUO & {$[45]$} \\
\hline Nitric oxide & $\begin{array}{l}\text { Vasodilator, anti-apoptotic, } \\
\text { antifibrotic }\end{array}$ & Decreased 14 days & Neonatal rat CUUO & {$[67,79]$} \\
\hline Renin & $\begin{array}{l}\text { Cleaves angiotensinogen, } \\
\text { upregulates } \\
\text { renin-angiotensin system }\end{array}$ & $\begin{array}{l}\text { Increased } 3 \text { days (mRNA) } \\
\text { Increased } 5 \text { days } \\
\text { Increased } 14 \text { days (mRNA) } \\
\text { Increased } 4-5 \text { weeks } \\
\text { Increased } 24 \mathrm{~h} \\
\text { Increased after mechanical stretch }\end{array}$ & $\begin{array}{l}\text { Neonatal rat CUUO } \\
\text { Neonatal rat CUUO } \\
\text { Neonatal rat CUUO } \\
\text { Neonatal rat CUUO } \\
\text { Adult rat CUUO } \\
\text { In vitro proximal tubular cells }\end{array}$ & $\begin{array}{l}{[71]} \\
{[39]} \\
{[63]} \\
{[80]} \\
{[81]} \\
{[82]}\end{array}$ \\
\hline TGF- $\beta$ & $\begin{array}{l}\text { Proinflammatory, } \\
\text { proapoptotic, profibrotic, } \\
\text { stimulates EMT }\end{array}$ & $\begin{array}{l}\text { Increased } 1 \text { day (mRNA) } \\
\text { Increased } 33 \text { days } \\
\text { Increased } 3 \text { days (mRNA) } \\
\text { Increased at pyeloplasty (mean age } 5 \text { years) }\end{array}$ & $\begin{array}{l}\text { Neonatal rat CUUO } \\
\text { Neonatal rat both CUUO and } \\
5 \text { day CUUO then release } \\
\text { Adult rat CUUO } \\
\text { Human renal biopsy }\end{array}$ & $\begin{array}{l}{[71]} \\
{[39]} \\
{[83]} \\
{[73]}\end{array}$ \\
\hline TIMP-1 & $\begin{array}{l}\text { Profibrotic, inhibits ECM } \\
\text { degradation }\end{array}$ & $\begin{array}{l}\text { Increased } 5 \text { days } \\
\text { Increased } 3 \text { days }\end{array}$ & $\begin{array}{l}\text { Adult rat CUUO } \\
\text { Adult mouse CUUO }\end{array}$ & $\begin{array}{l}{[84]} \\
{[74]}\end{array}$ \\
\hline TNF- $\alpha$ & $\begin{array}{l}\text { Proapoptotic, } \\
\text { proinflammatory }\end{array}$ & $\begin{array}{l}\text { Increased } 14 \text { days (mRNA) } \\
\text { Increased } 1 \text { day } \\
\text { Increased } 2 \text { days (mRNA) } \\
\text { Increased } 1 \text { day }\end{array}$ & $\begin{array}{l}\text { Neonatal rat CUUO } \\
\text { Adult rat CUUO } \\
\text { Adult rat CUUO } \\
\text { Adult rat CUUO }\end{array}$ & $\begin{array}{l}{[85]} \\
{[68]} \\
{[45]} \\
{[68]}\end{array}$ \\
\hline VCAM-1 & Proinflammatory & Increased 3 days (mRNA) & Adult mouse CUUO & {$[86]$} \\
\hline
\end{tabular}


Table 3 (continued)

\begin{tabular}{|c|c|c|c|c|}
\hline Protein $^{a}$ & Action & Change/timing & Species & Reference \\
\hline VEGF (podocytes) & Endothelial survival factor & $\begin{array}{l}\text { Increased } 28 \text { days } \\
\text { Decreased } 14 \text { days }\end{array}$ & $\begin{array}{l}\text { Neonatal PUUO } \\
\text { Neonatal CUUO }\end{array}$ & $\begin{array}{l}{[87]} \\
{[87]}\end{array}$ \\
\hline VEGF (tubules) & Endothelial survival factor & $\begin{array}{l}\text { Variable expression } \\
\text { Decreased } 14 \text { days }\end{array}$ & $\begin{array}{l}\text { Neonatal PUUO } \\
\text { Neonatal CUUO }\end{array}$ & $\begin{array}{l}{[87]} \\
{[87]}\end{array}$ \\
\hline Vimentin & $\begin{array}{l}\text { Intermediate filament protein/ } \\
\text { EMT marker }\end{array}$ & Increased 5 days & Neonatal rat CUUO & [39] \\
\hline WT-1 & $\begin{array}{l}\text { Transcriptional regulator, key } \\
\text { role in renal development }\end{array}$ & Decreased 14 days & Neonatal rat CUUO & {$[85]$} \\
\hline
\end{tabular}

Change is compared to sham animal or control human kidney and refers to protein expression unless otherwise stated. Timing is days after creation of unilateral ureteric obstruction (UUO)

CUUO, Complete UUO; $C B U O$ complete bilateral ureteric obstruction; PUUO, partial UUO

${ }^{a} \alpha$-SMA, Alpha-smooth muscle actin; COX-2, cyclooxygenase 2; CTGF, connective tissue growth factor; ECM, extracellular matrix; EGF, epidermal growth factor; EMT, epithelial-mesenchymal transition; FasL, Fas ligand; HSP-70, heat shock protein 70; ICAM-1, intercellular adhesion molecule 1; IL-6, interleukin-6; MCP-1, monocyte chemoattractant protein 1; MMP, matrix metalloproteinase; NF- $\mathrm{kB}$, nuclear factor kappa-light-chain-enhancer of activated B cells; TGF- $\beta$, transforming growth factor-beta; TIMP-1, tissue inhibitor of metalloproteinases 1 ; TNF- $\alpha$, tumour necrosis factor-alpha; VCAM-1, vascular cell adhesion molecule 1; VEGF, vascular endothelial growth factor; WT-1, Wilms tumor protein

the glomerulotubular junction, resulting in the formation of atubular glomeruli [41, 109].

TGF- $\beta 1$ is a profibrotic cytokine and fibroblast chemoattractant which plays a major role in fibrosis development via SMAD-dependent and -independent pathways (Fig. 7) [74-76, 114-118]. Renal TGF- $\beta$ expression is increased in experimental UUO $[83,103,105,107,119-121]$ and children with PUJO, being positively correlated with the histopathologic grade, radioisotope drainage half time $(\mathrm{t} 1 / 2)$ and postvoid washout and negatively correlated with pre-operative differential renal function $[73,122]$.

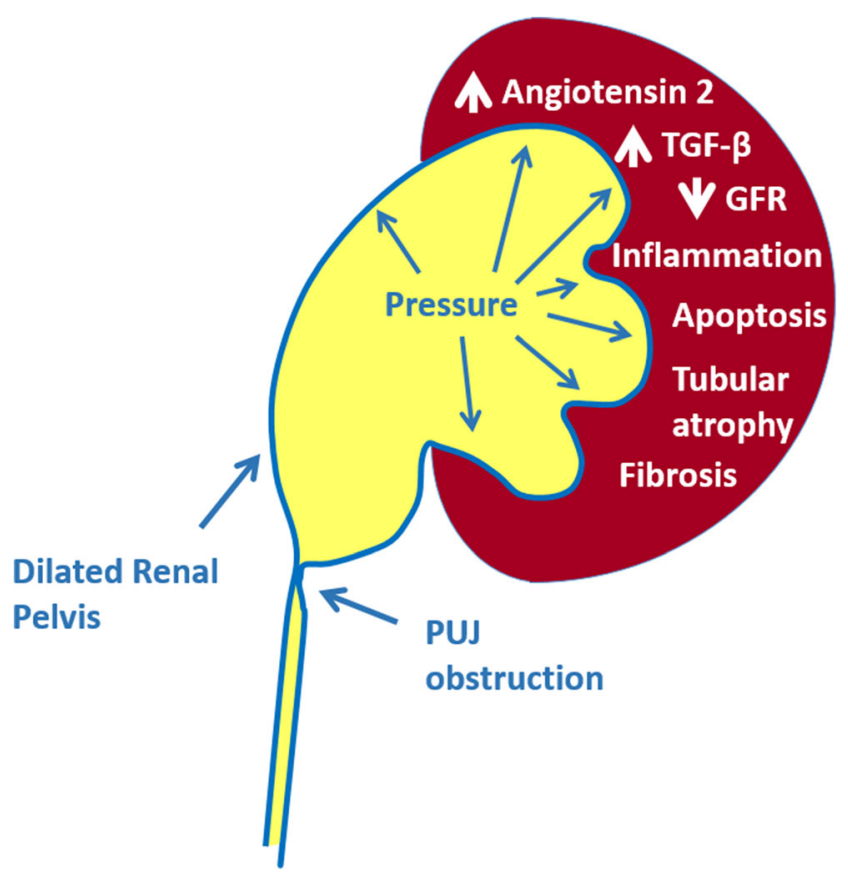

Fig. 5 Major mechanisms of renal injury in PUJO. GFR glomerular filtration rate, $T G F$ transforming growth factor

Nitric oxide is an endogenous vasodilator that protects against tubulointerstitial fibrosis and proximal tubular oxidant injury in obstructive nephropathy [79, 84, 123]. Animal models $[111,124,125]$ and human studies of PUJO show altered endothelial NO synthase (eNOS) and inducible NO synthase (iNOS) expression/activity together with reduced NO production. Lower eNOS expression/activity is associated with worse creatinine clearance, reduced differential renal function [90, 126] and increased fibrosis [90, 126], oxidant injury and apoptosis $[67,79]$.

\section{Antifibrotic processes}

Renal cyclooxygenase 2 (COX-2) expression and prostaglandin production in experimental UUO is increased [69] and may be a protective response. COX-2 inhibition worsens obstructive nephropathy, while prostacyclin analogue

Table 4 Cytokines, growth factors, enzymes and adhesion molecules promoting or preventing tubulointerstitial fibrosis in ureteric obstruction

\begin{tabular}{ll}
$\begin{array}{l}\text { Molecules } \\
\text { PROMOTING } \\
\text { tubulointerstitial } \\
\text { fibrosis in ureteric } \\
\text { obstruction }\end{array}$ & $\begin{array}{l}\text { Molecules } \\
\text { tubulointerstitial } \\
\text { fibrosis in ureteric } \\
\text { obstruction }\end{array}$ \\
\hline Angiotensin II & EGF \\
CTGF & MMP \\
ICAM-1 & Nitric oxide \\
Integrins & VEGF \\
PAI-1 & \\
PDGF & \\
TGF- $\beta$ & \\
TIMP-1 & \\
\hline
\end{tabular}

PAI-1, Plasminogen activator inhibitor 1; PDGF, platelet-derived growth factor 
Fig. 6 Major pathways involved in the development of obstructive nephropathy derived from animal and human studies. ET-1

Endothelin 1, iNOS inducible nitric oxide synthase, $P T$ proximal tubule, RAAS reninangiotensin-aldosterone system, RANTES regulated on activation normal T-cell expressed and secreted, $R B F$ renal blood flow, $R O S$ reactive oxygen species. For other abbreviations, see footnotes to Tables 3 and 4

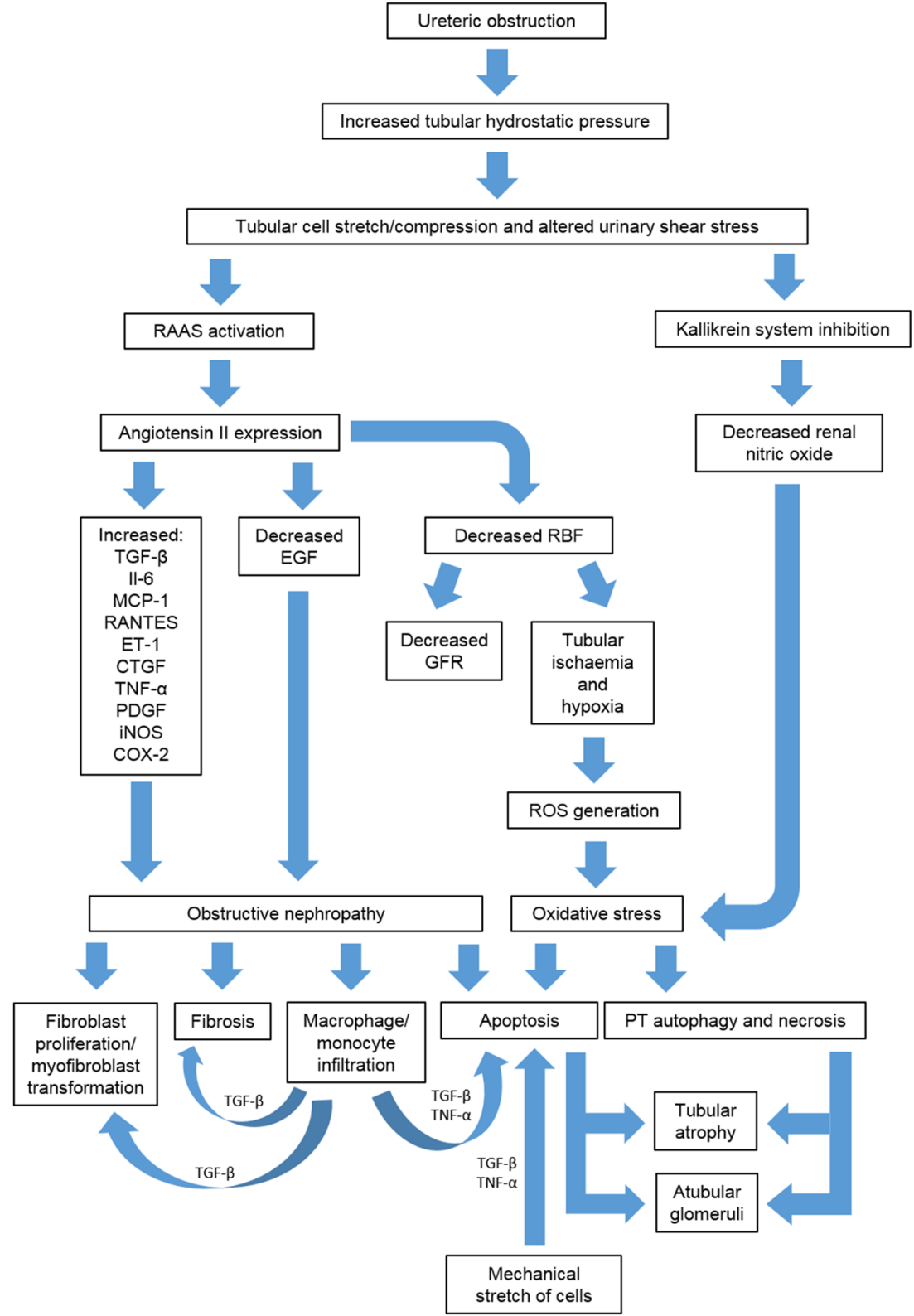

(ONO-1301) supplementation alleviates UUO-induced fibrosis [127].

\section{Cellular apoptosis}

Apoptosis affects podocytes and endothelial and epithelial cells within the kidney, leading to loss of glomeruli, peritubular capillaries and tubules [11]. Tubular cell mechanical stretch is a potent stimulator of apoptosis $[91,128]$ that is mediated via TGF- $\beta 1$ and TNF- $\alpha[68,110]$ released from tubular cells and infiltrating macrophages [88]. Other proapoptotic factors increased after UUO include Fas-L [45], p53, caspases and ceramide [11].
Downregulation of anti-apoptotic factors, including EGF, eNOS, NO, vascular endothelial growth factor, heat shock protein 70 and Wilms tumour-1, compounds the renal injury $[11,67,88,128,129]$.

\section{Tubular function impairment}

Ureteric obstruction leads to reduced renal expression of the V2 (vasopressin) receptor [130], renal sodium and urea transporters [131-133] and aquaporins [134-136]. Aquaporins are a family of transmembrane proteins normally expressed by mammalian kidney [137] and urothelium [138, 139] that mediate water movement across the cell membrane along an osmotic gradient [140]. Reduced renal aquaporin expression 


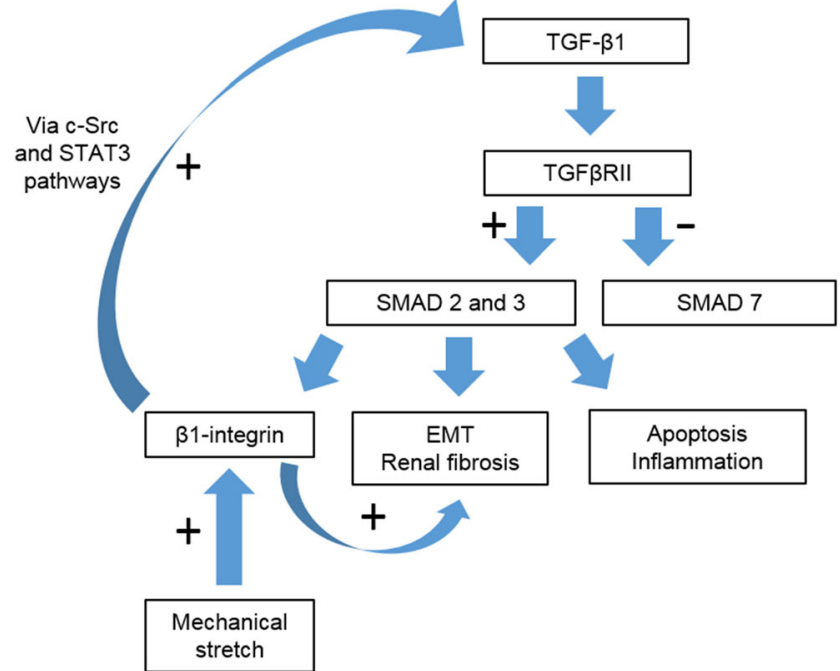

Fig. 7 Transforming growth factor $\beta 1(T G F-\beta 1)$ signalling via the SMAD-dependent pathway. Unilateral ureteric obstruction induces increased TGF- $\beta 1$ and TGF- $\beta$ receptor II (TGF $\beta R I I)$ expression, upregulating SMAD 2 and 3 and downregulating SMAD 7 (inhibitory for SMAD 2 and 3). $\beta 1$-integrin is upregulated by both SMAD signalling and mechanical stretch and contributes to a positive feedback loop regulating TGF- $\beta 1$ expression via the c-SRC and STAT- 3 pathways. EMT Epithelial mesenchymal transformation

in experimental UUO is noted within $24 \mathrm{~h}$ of complete obstruction [134]. Similarly, renal aquaporins are downregulated in children undergoing pyeloplasty, and in both human and animal models this reduction is associated with polyuria and reduced concentrating ability following relief of obstruction [141-143].

\section{Genetic mechanistic clues in PUJO}

Phenotypes similar to PUJO have been noted in numerous transgenic mouse models. Many genes involved in ureteric smooth muscle proliferation and differentiation are implicated, supporting a primary myogenic aetiology. Importantly, one of these genes has been implicated in human disease (Table 2).

Mutations in TBX18, the gene coding for $\mathrm{T}$ Box protein 18 , have been reported in association with congenital anomalies of the kidney and urinary tract (CAKUT). In particular, a heterozygous $T B X 18$ truncating mutation (c.1010delG) showing autosomal dominant inheritance has been described across four generations of a family with CAKUT, and predominantly PUJO [56]. The transcription factor TBX18 is necessary for normal smooth muscle cell proliferation, differentiation and localisation around the developing urothelial stalk [24]. TBX18 also directs epithelial proliferation and when absent leads to an abnormally short ureteric bud [28].
In the majority of patients, however, PUJO is a polygenic disorder without an obviously inherited genetic component [11].

\section{Potential therapeutic molecular targets in PUJO}

Human and animal studies have highlighted a number of potential therapeutic targets that could be manipulated to alleviate the nephropathy sustained secondary to PUJO. Several drugs targeting these pathways have been assessed in rodent UUO models as described below, however, to our knowledge none of these therapies have been trialed in childhood human PUJO.

\section{Angiotensin-converting enzyme and AT1 receptor inhibitors}

In adult rodent UUO models angiotensin-converting enzyme (ACE) inhibitors and AT1 receptor inhibitors given prophylactically (for the duration of obstruction) are beneficial in alleviating nephropathy. Specifically, they reduce TGF- $\beta$ $[121,144]$ and TNF- $\alpha$ [106] expression, as well as macrophage infiltration and tubulointerstitial fibrosis $[84,105$, 145]. Additionally, AT1 receptor inhibitors improve tubular function by improving RBF and GFR and attenuating the reduction in sodium transporter and aquaporin 2 (AQP2) expression, thus reducing polyuria and natriuresis $[92,112]$.

ACE inhibitors reduce both AT1 and AT2 receptor stimulation [146] and indirectly increase NO levels via bradykinin generation [84]. This may explain why they confer additional benefits, particularly anti-inflammatory, compared to AT1 receptor inhibitors [97]. Unfortunately, inhibition of angiotensin during either the period of nephrogenesis (first 10 days after UUO) or renal maturation (second 10 days after UUO) in neonatal partial UUO exacerbates renal injury in both the obstructed and contralateral kidney [147, 148]. Such studies highlight the importance of these pathways in normal kidney development and maturation.

However, it is important to remember that ACE inhibitors and AT1 receptor inhibitors are frequently used in children with chronic kidney disease, in whom they significantly reduce proteinuria [149] despite not significantly alleviating the natural decline in excretory function $[150,151]$. They are largely well tolerated, with no apparent effect on growth and development and a low incidence of side effects such as hyperkalaemia, hypotension and renal injury [149].

\section{Hydroxymethylglutaryl-CoA reductase inhibitors (statins)}

Statins ameliorate nephropathy when administered prophylactically in adult and neonatal rodent UUO models by reducing 
renal cytokine production (TGF- $\beta$, TNF- $\alpha$ ), macrophage infiltration, oxidative stress, apoptosis and tubulointerstitial fibrosis $[85,152,153]$. These pleiotropic effects are achieved through decreased Ras/ERK/Akt signalling [154] and increased NO bioavailability [155]. Importantly, statins remain beneficial in neonatal rodent UUO where an improvement in tubular dilatation and glomerular number and size are also seen $[67,79,85]$. Functionally, in UUO models, statins improve GFR and microalbuminuria [156] and increase urinary concentrating ability via boosting AQP2 expression [157].

Statins are commonly used and usually well tolerated in adults. Side effects of treatment include hepatic dysfunction, diabetes mellitus, benign proteinuria, peripheral neuropathy, myalgia and rhabdomyolysis [158]. A 10-year follow-up study of children ( $\geq 8$ years) treated with statins for familial hypercholesterolaemia demonstrated that few discontinue therapy due to side effects and that there were no serious adverse reactions [159]. In that same study, growth, puberty and educational parameters were also unaffected compared to controls [159].

\section{TGF- $\beta$ modulation}

Prophylactic TGF- $\beta$ receptor inhibition is renoprotective in adult rodent UUO models, reducing apoptosis, macrophage infiltration, fibrosis, proximal tubular atrophy and atubular glomeruli formation $[117,160]$. Similarly, anti-TGF- $\beta$ antibody treatment increases NOS expression while reducing apoptosis and fibrosis [110]. Conversely, prophylactic TGF- $\beta$ receptor inhibition in neonatal mouse UUO causes widespread renal necrosis, exacerbating the injury in the obstructed kidney and highlighting the differing responses to signalling cascades during renal development [117].

Anti-TGF- $\beta$ antibody treatment (GC1008) has been trialled in human oncological disease and was generally well tolerated. However, side effects included gingivitis, fatigue and skin rashes, including keratoacanthoma and squamous cell carcinoma development (melanoma patients only). GC1008 treatment has not progressed beyond phase II clinical trials as drug development was discontinued by the manufacturer [161].

\section{COX-2 inhibition}

In adult rodent bilateral ureteric obstruction COX-2 inhibition alleviates AQP2 and sodium transporter downregulation and improves post-obstructive polyuria, which would appear to be beneficial [69]. Conversely, other studies have demonstrated that both genetic COX-2 knockout and prophylactic COX-2 inhibition in adult rodent UUO models increase tubular injury, apoptosis and fibrosis, thereby negating potential use in the clinical setting $[70,162]$.
Chronic celecoxib (COX-2 inhibitor) use in children demonstrates a similar frequency of adverse events to nonselective non-steroidal anti-inflammatory drugs, which are most frequently gastrointestinal side effects [163].

\section{Other potential therapeutic options}

Other potential therapeutic pathways include those that are able to increase the vasoactive molecule $\mathrm{NO}$, as this has been shown to reduce tubulointerstitial fibrosis in adult rodent UUO models [84]. Although both ACE inhibitors and statins increase NO bioavailability, this is an indirect effect at the expense of drug-related side effects.

Dietary nitrate supplementation is a novel therapeutic option which directly targets the NO pathway, increasing NO generation via nitrite production. Nitrite also has cytoprotective effects independent of NO by influencing mitochondrial function [164], and when administered during rodent ischaemia reperfusion studies reduces renal injury [165].

Despite former concerns associating nitrates with methaemoglobinaemia and carcinogenesis, the nitratenitrite-NO pathway is increasingly implicated in a protective role in humans [166]. Further investigation of dietary nitrate supplementation as a potential therapy in obstructive nephropathy is warranted.

\section{Urinary biomarkers}

Identifying early urinary biomarkers in PUJO may be beneficial for the diagnosis, management and prognosis of this condition. Such biomarkers would enable timely detection of children with 'damaging' hydronephrosis who require surgery to protect renal function, while avoiding surgery in those with 'safe' hydronephrosis.

\section{Urinary biomarkers in animal studies}

There is little data on urinary biomarkers from animal studies. Proteomics using a rat UUO model demonstrated increased urinary and renal levels of alpha-actinin-1 and moesin at 1 week which corresponded with histological evidence of tubular injury. Following 3 weeks of UUO urine and renal levels of vimentin, annexin A1 and clusterin were significantly elevated, corresponding with substantial renal interstitial fibrosis [167].

\section{Urinary biomarkers in human studies}

Many urinary cytokines, growth factors, chemokines, tubular enzymes and tubular transport proteins have been investigated 
Table 5 Urinary proteins from studies in children with pelvi-ureteric junction obstruction

\begin{tabular}{|c|c|c|c|c|c|c|}
\hline $\begin{array}{l}\text { Urinary protein } \\
\text { (corrected for } \\
\text { creatinine) })^{\mathrm{a}}\end{array}$ & $\begin{array}{l}\text { Primary } \\
\text { measured } \\
\text { group }\end{array}$ & Comparators & Bladder urine protein level & $\begin{array}{l}\text { Sensitivity/ } \\
\text { specificity/ } \\
\text { accuracy }{ }^{b}\end{array}$ & $\begin{array}{l}\text { Post-operative bladder urine } \\
\text { (compared to pre-operative) }\end{array}$ & Ref \\
\hline ALP & Pyeloplasty & CMP & Increased pre-operative & $\begin{array}{l}\text { Se } 91.4 \% / \mathrm{Sp} \\
100 \% / \mathrm{Ac} 94 \%\end{array}$ & $\begin{array}{l}\text { Decreased } 12 \text { months } \\
\text { post-operative }\end{array}$ & [168] \\
\hline Angiotensinogen & Pyeloplasty & $\begin{array}{l}\text { Healthy control } \\
\text { CMP }\end{array}$ & Increased pre-operative & $\begin{array}{l}\text { Se } 93.3 \% \%^{\mathrm{c} / \mathrm{Sp}} \\
\quad 60 \%\end{array}$ & & [169] \\
\hline B2-microglobulin & PUJO* & Healthy control & Increased & & $\begin{array}{l}\text { Decreased } 42 \text { months } \\
\text { post-operative }\end{array}$ & [170] \\
\hline B2-microglobulin & Pyeloplasty & Healthy control & No change & & & [171] \\
\hline Ca19-9 & Pyeloplasty & $\begin{array}{l}\text { Healthy control } \\
\text { CMP }\end{array}$ & Increased pre-operative & Se $76 \%{ }^{\mathrm{d}} / \mathrm{Sp} 85 \%^{\mathrm{d}}$ & $\begin{array}{l}\text { Decreased } 3 \text { months } \\
\text { post-operative }\end{array}$ & [172] \\
\hline Ca19-9 & Pyeloplasty & $\begin{array}{l}\text { Healthy control } \\
\text { Hydrocoele/renal } \\
\text { cyst }\end{array}$ & Increased pre-operative & $\begin{array}{l}\text { Se } 100 \% \text { / Sp } \\
\quad 82.6 \%{ }^{\mathrm{e}}\end{array}$ & $\begin{array}{l}\text { Decreased } 3 \text { months } \\
\text { post-operative }\end{array}$ & [173] \\
\hline $\mathrm{CyC}$ & Pyeloplasty & Healthy control & No change & & & [171] \\
\hline EGF & PUJO* & Healthy control & $\begin{array}{l}\text { Decreased (obstructed group } \\
\text { only) }\end{array}$ & & No change & [170] \\
\hline EGF & Pyeloplasty & Healthy control & Decreased pre-operative & & Increased & [174] \\
\hline EGF & Pyeloplasty & Healthy control & Increased pre-operative & $\begin{array}{l}\text { Se } 70.4 \% / \mathrm{Sp} \\
\quad 69.2 \%\end{array}$ & $\begin{array}{l}\text { Decreased } 3 \text { months and } 1 \text { year } \\
\text { post-operative }\end{array}$ & [175] \\
\hline EGF & Pyeloplasty & Healthy control & No change & & & [176] \\
\hline ET-1 & Pyeloplasty & $\begin{array}{l}\text { Healthy control } \\
\text { VUR } \\
\text { Renal stones }\end{array}$ & Increased pre-operative & $\begin{array}{l}\text { Se } 74.3 \% / \mathrm{Sp} 90 \% / \\
\quad \text { Ac } 81.5 \%\end{array}$ & $\begin{array}{l}\text { Decreased } 12 \text { months } \\
\text { post-operative }\end{array}$ & [177] \\
\hline$\gamma \mathrm{GT}$ & Pyeloplasty & CMP & Increased pre-operative & $\begin{array}{l}\text { Se } 62.9 \% / \mathrm{Sp} \\
100 \% / \mathrm{Ac} 74 \%\end{array}$ & $\begin{array}{l}\text { Decreased } 12 \text { months } \\
\text { post-operative }\end{array}$ & [168] \\
\hline HO-1 & Pyeloplasty & $\begin{array}{l}\text { Healthy control } \\
\text { CMP }\end{array}$ & Increased pre-operative & $\begin{array}{l}\text { Se } 72.2 \%^{\mathrm{c}} / \mathrm{Sp} \\
\quad 78.1 \%^{\mathrm{c}}\end{array}$ & $\begin{array}{l}\text { Decreased } 1 \text { month } \\
\text { post-operative }\end{array}$ & [178] \\
\hline IP-10 & Pyeloplasty & Healthy control & No change & & & [175] \\
\hline KIM-1 & Pyeloplasty & $\begin{array}{l}\text { Healthy control } \\
\text { CMP }\end{array}$ & Increased pre-operative & $\begin{array}{l}\text { Se } 100 \% \%^{\mathrm{c}} / \mathrm{Sp} \\
71.4 \%^{\mathrm{c}}\end{array}$ & & [179] \\
\hline MCP-1 & Pyeloplasty & Healthy control & Increased pre-operative & $\begin{array}{l}\mathrm{Se} 77.8 \% / \mathrm{Sp} \\
\quad 69.2 \%\end{array}$ & $\begin{array}{l}\text { Decreased } 3 \text { months and } 1 \text { year } \\
\text { post-operative }\end{array}$ & [175] \\
\hline MCP-1 & PUJO* & Healthy control & Increased & & $\begin{array}{l}\text { Decreased } 42 \text { months } \\
\text { post-operative }\end{array}$ & [170] \\
\hline MCP-1 & Pyeloplasty & Healthy control & Increased pre-operative & & & [174] \\
\hline MCP-1 & Pyeloplasty & $\begin{array}{l}\text { Healthy control } \\
\text { CMP }\end{array}$ & Increased pre-operative & Se $100 \%^{\mathrm{c}} / \mathrm{Sp} 0 \%^{\mathrm{c}}$ & $\begin{array}{l}\text { Remains high } 3 \text { months } \\
\text { post-operative }\end{array}$ & [180] \\
\hline MIP- $1 \alpha$ & Pyeloplasty & Healthy control & Decreased pre-operative & & Increased 1 year post-operative & [175] \\
\hline NAG & Pyeloplasty & $\mathrm{CMP}$ & Increased pre-operative & $\begin{array}{l}\text { Se } 97.1 \% / \mathrm{Sp} \\
80 \% / \mathrm{Ac} 92 \%\end{array}$ & $\begin{array}{l}\text { Decreased } 12 \text { months } \\
\text { post-operative }\end{array}$ & [168] \\
\hline NGAL & Pyeloplasty & Healthy control & No change & & & [171] \\
\hline NGAL & Pyeloplasty & Healthy control & Increased pre-operative & & & [181] \\
\hline NGAL & Pyeloplasty & $\begin{array}{l}\text { Healthy control } \\
\text { CMP }\end{array}$ & Increased pre-operative & $\begin{array}{l}\text { Se } 100 \% \%^{\mathrm{c}} / \mathrm{Sp} \\
28.6 \%{ }^{\mathrm{c}}\end{array}$ & $\begin{array}{l}\text { Decreased } 3 \text { months } \\
\text { post-operative }\end{array}$ & [179] \\
\hline OPN & Pyeloplasty & Healthy control & No change & & & [171] \\
\hline OPN & Pyeloplasty & $\begin{array}{l}\text { Healthy control } \\
\text { CMP }\end{array}$ & Increased pre-operative & $\begin{array}{c}\text { Se } 98.5 \% \text { c } / \mathrm{Sp} \\
10.5 \%^{\mathrm{c}}\end{array}$ & $\begin{array}{l}\text { Remains high } 3 \text { months } \\
\text { post-operative }\end{array}$ & [180] \\
\hline RANTES & Pyeloplasty & Healthy control & No change & & & [175] \\
\hline TGF- $\beta$ & Pyeloplasty & Healthy control & Increased pre-operative & $\begin{array}{l}\text { Se } 100 \% / \mathrm{Sp} \\
\quad 80 \% / \mathrm{Ac} 90.8 \%\end{array}$ & Decreased 1 year post-operative & [176] \\
\hline TGF- $\beta$ & Pyeloplasty & CMP & Increased pre-operative & Se $82 \% / \mathrm{Sp} 86 \%$ & & [182] \\
\hline
\end{tabular}

Generally, the primary group measured is children undergoing pyeloplasty; these children are then compared to healthy controls and/or conservatively managed children with PUJO (CMP). The exception in the studies listed in the table is labelled PUJO*, which includes children with conservatively managed PUJO split into 'functional' (t1/2 of renogram $<0 \mathrm{~min}$ ) and 'obstructed' (t1/2 of renogram $>20 \mathrm{~min}$ ). In these studies voided urine from children undergoing pyeloplasty was only obtained 42 months post-operative

${ }^{a}$ ALP, Alkaline phosphatase; Ca19-9, carbohydrate antigen 19-9; CyC, cystatin-C; HO-1, heme oxygenase-1; $\gamma$ GT, gamma-glutamyl transferase; IP-10, interferon- $\gamma$-inducible protein 10 ; KIM-1, kidney injury molecule-1; MIP-1 $\alpha$, macrophage inflammatory protein- $1 \alpha$; NAG, $N$-acetyl-beta-Dglucosaminidase; NGAL, neutrophil gelatinase-associated lipocali; OPN, osteopontinn, RANTES, regulated on activation normal T-cell expressed and secreted

${ }^{\mathrm{b}}$ Where applicable sensitivity (Se), specificity (Sp) and accuracy (Ac) of the test at best threshold value from receiver operating characteristic curve analysis is presented

${ }^{\mathrm{c}}$ To detect differential renal function (DRF) of $<40 \%$ out of all hydronephrosis cases

${ }^{\mathrm{d}}$ To detect pyeloplasty cases out of all hydronephrosis cases

${ }^{\mathrm{e}}$ To detect pyeloplasty cases out of all cases 
in children undergoing pyeloplasty for PUJO. Studies with conservatively managed PUJO as a comparator are most useful to identify biomarkers able to aid selection of patients for surgery. Potential urinary biomarker proteins measured in bladder urine samples are presented in Table 5 .

Finding a suitable biomarker test with high sensitivity, specificity and predictive value is challenging [88], not least because these markers are excreted in health as well as disease, show significant intra- and inter-patient variation and may be affected by patient age, the presence of urinary tract infection and other renal disorders [174, 183].

A recent systematic review of urinary and serum biomarkers included 14 studies which reported data on 380 surgically managed PUJO patients, 174 conservatively managed patients and 213 controls [184]. This review reported a wide-range of sometimes conflicting results, and the authors were unable to draw any firm conclusions, attributing this to differences in study design with heterogeneous age groups, various or absent control groups and often short durations of follow-up [184].

More successfully, proteomics of neonatal urine has identified a panel of 51 peptides which distinguish obstruction severity. When implemented in a prospective blinded study it had an accuracy of $94 \%$ to predict future need for surgery in newborns with PUJO [185]. However, beyond 1 year of age the sensitivity and specificity of this proteome profile diminished significantly [186].

A single biomarker able to guide selection of patients for pyeloplasty has not yet been identified, indicating a panel of biomarkers may be necessary to achieve this.

\section{Conclusions}

Managing children with asymptomatic intrinsic PUJO is a significant challenge for clinicians. Animal and human studies have expanded our understanding of the molecular mechanisms involved in the aetiology of obstruction and in particular the progression of the renal insult. Upregulation of the RAAS and TGF- $\beta$ expression are fundamental to renal injury, which is attenuated in animal models by therapeutic inhibition of these pathways. Much, however, remains to be learned in order to identify molecular markers and targets useful in the day-to-day diagnosis and management of this condition.

\section{Future perspectives and unanswered questions in PUJO}

- What is the underlying aetiology of intrinsic congenital PUJO? Does this explain the variable outcome of PUJO and can this be targeted therapeutically?
- Does individual ability to relieve intra-renal pressure determine disease progression?

- Are therapies tested in animals applicable in children to limit renal injury?

- Can urinary biomarkers improve early identification and thus outcome of children requiring pyeloplasty?

\section{Compliance with ethical standards}

Funding Laura Jackson is funded by a joint Royal College of Surgeons of England/British Association of Paediatric Surgeons Fellowship (Awarded 2014). Richard Coward is funded by the Medical Research Council as a Senior Clinical Fellow MR/K010492/1.

Conflict of interest The authors declare that they have no conflict of interest.

Open Access This article is distributed under the terms of the Creative Commons Attribution 4.0 International License (http:// creativecommons.org/licenses/by/4.0/), which permits unrestricted use, distribution, and reproduction in any medium, provided you give appropriate credit to the original author(s) and the source, provide a link to the Creative Commons license, and indicate if changes were made.

\section{References}

1. Dudley JA, Haworth JM, McGraw ME, Frank JD, Tizard EJ (1997) Clinical relevance and implications of antenatal hydronephrosis. Arch Dis Child Fetal Neonatal Ed 76:F31-34

2. Brussels Free University Perinatal Nephrology Study Group, Ismaili K, Avni FE, Wissing KM, Hall M (2004) Long-term clinical outcome of infants with mild and moderate fetal pyelectasis: validation of neonatal ultrasound as a screening tool to detect significant nephrouropathies. J Pediatr 144:759-765

3. Jaswon MS, Dibble L, Puri S, Davis J, Young J, Dave R, Morgan H (1999) Prospective study of outcome in antenatally diagnosed renal pelvis dilatation. Arch Dis Child Fetal Neonatal Ed 80: F135-138

4. Woodward M, Frank D (2002) Postnatal management of antenatal hydronephrosis. BJU Int 89:149-156

5. Morris RK, Kilby MD (2008) Congenital urinary tract obstruction. Best Pract Res Clin Obstet Gynaecol 22:97-122

6. Corbett HJ, McCarthy L (2013) Hydronephrosis in children: pelviureteric junction dysfunction. Surgery (Oxford) 31:135-139

7. Hashim H, Woodhouse CRJ (2012) Ureteropelvic junction obstruction. Eur Urol Suppl 11:25-32

8. Ulman I, Jayanthi VR, Koff SA (2000) The long-term followup of newborns with severe unilateral hydronephrosis initially treated nonoperatively. J Urol 164:1101-1105

9. Hafez AT, McLorie G, Bagli D, Khoury A (2002) Analysis of trends on serial ultrasound for high grade neonatal hydronephrosis. J Urol 168(4 Pt 1):1518-1521

10. Chertin B, Pollack A, Koulikov D, Rabinowitz R, Hain D, HadasHalpren I, Farkas A (2006) Conservative treatment of ureteropelvic junction obstruction in children with antenatal diagnosis of hydronephrosis: lessons learned after 16 years of followup. Eur Urol 49:734-738

11. Chevalier RL, Thornhill BA, Forbes MS, Kiley SC (2010) Mechanisms of renal injury and progression of renal disease in congenital obstructive nephropathy. Pediatr Nephrol 25:687-697 
12. Gordon I, Dhillon HK, Gatanash H, Peters AM (1991) Antenatal diagnosis of pelvic hydronephrosis: assessment of renal function and drainage as a guide to management. J Nucl Med 32:1649 1654

13. Ransley PG, Dhillon HK, Gordon I, Duffy PG, Dillon MJ, Barratt TM (1990) The postnatal management of hydronephrosis diagnosed by prenatal ultrasound. The J Urol 144(2 Pt 2):584-587, discussion 593-584

14. Csaicsich D, Greenbaum LA, Aufricht C (2004) Upper urinary tract: when is obstruction obstruction? Curr Opin Urol 14:213217

15. Stringer MD, Yassaie S (2013) Is the pelviureteric junction an anatomical entity? J Pediatr Urol 9:123-128

16. Shafik A, Al-Sherif A (1999) Ureteropelvic junction: a study of its anatomical structure and function. Ureteropelvic junction sphincter? Eur Urol 36:150-156, discussion 156-157

17. Santicioli P, Maggi CA (1998) Myogenic and neurogenic factors in the control of pyeloureteral motility and ureteral peristalsis. Pharmacol Rev 50:683-722

18. Nemeth L, O'Briain DS, Puri P (2001) Demonstration of neuronal networks in the human upper urinary tract using confocal laser scanning microscopy. J Urol 166:255-258

19. Takasato M, Little MH (2015) The origin of the mammalian kidney: implications for recreating the kidney in vitro. Development 142:1937-1947

20. Nagalakshmi VK, Yu J (2015) The ureteric bud epithelium: morphogenesis and roles in metanephric kidney patterning. Mol Reprod Dev 82:151-166

21. Yu J, Carroll TJ, McMahon AP (2002) Sonic hedgehog regulates proliferation and differentiation of mesenchymal cells in the mouse metanephric kidney. Development 129:5301-5312

22. Brenner-Anantharam A, Cebrian C, Guillaume R, Hurtado R, Sun TT, Herzlinger D (2007) Tailbud-derived mesenchyme promotes urinary tract segmentation via BMP4 signaling. Development 134:1967-1975

23. Caubit X, Lye CM, Martin E, Core N, Long DA, Vola C, Jenkins D, Garratt AN, Skaer H, Woolf AS, Fasano L (2008) Teashirt 3 is necessary for ureteral smooth muscle differentiation downstream of SHH and BMP4. Development 135:3301-3310

24. Airik R, Bussen M, Singh MK, Petry M, Kispert A (2006) Tbx18 regulates the development of the ureteral mesenchyme. J Clin Invest 116:663-674

25. Mahoney ZX, Sammut B, Xavier RJ, Cunningham J, Go G, Brim KL, Stappenbeck TS, Miner JH, Swat W (2006) Discs-large homolog 1 regulates smooth muscle orientation in the mouse ureter. Proc Natl Acad Sci USA 103:19872-19877

26. Crelin ES (1978) Normal and abnormal development of ureter. Urology 12:2-7

27. Alcaraz A, Vinaixa F, Tejedo-Mateu A, Fores MM, Gotzens V, Mestres CA, Oliveira J, Carretero P (1991) Obstruction and recanalization of the ureter during embryonic development. J Urol 145: 410-416

28. Woolf AS, Davies JA (2013) Cell biology of ureter development. J Am Soc Nephrol 24:19-25

29. Matsuno T, Tokunaka S, Koyanagi T (1984) Muscular development in the urinary tract. J Urol 132:148-152

30. Chang CP, McDill BW, Neilson JR, Joist HE, Epstein JA, Crabtree GR, Chen F (2004) Calcineurin is required in urinary tract mesenchyme for the development of the pyeloureteral peristaltic machinery. J Clin Invest 113:1051-1058

31. Miyazaki Y, Tsuchida S, Nishimura H, Pope JC 4th, Harris RC, McKanna JM, Inagami T, Hogan BL, Fogo A, Ichikawa I (1998) Angiotensin induces the urinary peristaltic machinery during the perinatal period. J Clin Invest 102:1489-1497
32. Zhang PL, Peters CA, Rosen S (2000) Ureteropelvic junction obstruction: morphological and clinical studies. Pediatr Nephrol 14:820-826

33. Murakumo M, Nonomura K, Yamashita T, Ushiki T, Abe K, Koyanagi T (1997) Structural changes of collagen components and diminution of nerves in congenital ureteropelvic junction obstruction. J Urol 157:1963-1968

34. Demirbilek S, Edali MN, Gurunluoglu K, Turkmen E, Tas E, Karaman A, Akin M, Aksoy RT, Celbis O, Uzun I (2006) Glial cell line-derived neurotrophic factor and synaptophysin expression in pelviureteral junction obstruction. Urology 67:400-405

35. Ozel SK, Emir H, Dervisoglu S, Akpolat N, Senel B, Kazez A, Soylet Y, Cetin G, Danismend N, Buyukunal SN (2010) The roles of extracellular matrix proteins, apoptosis and c-kit positive cells in the pathogenesis of ureteropelvic junction obstruction. J Pediatr Urol 6:125-129

36. Kaneto H, Orikasa S, Chiba T, Takahashi T (1991) Three-D muscular arrangement at the ureteropelvic junction and its changes in congenital hydronephrosis: a stereo-morphometric study. J Urol 146:909-914

37. Hosgor M, Karaca I, Ulukus C, Ozer E, Ozkara E, Sam B, Ucan B, Kurtulus S, Karkiner A, Temir G (2005) Structural changes of smooth muscle in congenital ureteropelvic junction obstruction. J Pediatr Surg 40:1632-1636

38. Aoki Y, Mori S, Kitajima K, Yokoyama O, Kanamaru H, Okada $\mathrm{K}$, Yokota Y (2004) Id2 haploinsufficiency in mice leads to congenital hydronephrosis resembling that in humans. Genes Cells 9: 1287-1296

39. Chevalier RL, Kim A, Thornhill BA, Wolstenholme JT (1999) Recovery following relief of unilateral ureteral obstruction in the neonatal rat. Kidney Int 55:793-807

40. Chevalier RL, Thornhill BA, Wolstenholme JT (1999) Renal cellular response to ureteral obstruction: role of maturation and angiotensin II. Am J Physiol 277(1 Pt 2):F41-47

41. Forbes MS, Thornhill BA, Chevalier RL (2011) Proximal tubular injury and rapid formation of atubular glomeruli in mice with unilateral ureteral obstruction: a new look at an old model. Am J Physiol Ren Physiol 301:F110-117

42. Forbes MS, Thornhill BA, Galarreta CI, Minor JJ, Gordon KA, Chevalier RL (2013) Chronic unilateral ureteral obstruction in the neonatal mouse delays maturation of both kidneys and leads to late formation of atubular glomeruli. Am J Physiol Ren Physiol 305:F1736-1746

43. Lange-Sperandio B, Cachat F, Thornhill BA, Chevalier RL (2002) Selectins mediate macrophage infiltration in obstructive nephropathy in newborn mice. Kidney Int 61:516-524

44. Lange-Sperandio B, Schimpgen K, Rodenbeck B, Chavakis T, Bierhaus A, Nawroth P, Thornhill B, Schaefer F, Chevalier RL (2006) Distinct roles of Mac-1 and its counter-receptors in neonatal obstructive nephropathy. Kidney Int 69:81-88

45. Esteban V, Lorenzo O, Ruperez M, Suzuki Y, Mezzano S, Blanco J, Kretzler M, Sugaya T, Egido J, Ruiz-Ortega M (2004) Angiotensin II, via AT1 and AT2 receptors and NF-kappaB pathway, regulates the inflammatory response in unilateral ureteral obstruction. J Am Soc Nephrol 15:1514-1529

46. Thornhill BA, Burt LE, Chen C, Forbes MS, Chevalier RL (2005) Variable chronic partial ureteral obstruction in the neonatal rat: a new model of ureteropelvic junction obstruction. Kidney Int $67: 42-52$

47. Thornhill BA, Forbes MS, Marcinko ES, Chevalier RL (2007) Glomerulotubular disconnection in neonatal mice after relief of partial ureteral obstruction. Kidney Int 72:1103-1112

48. Klein J, Gonzalez J, Miravete M, Caubet C, Chaaya R, Decramer S, Bandin F, Bascands JL, Buffin-Meyer B, Schanstra JP (2011) Congenital ureteropelvic junction obstruction: human disease and animal models. Int J Exp Pathol 92:168-192 
49. Wang Y, Puri P, Hassan J, Miyakita H, Reen DJ (1995) Abnormal innervation and altered nerve growth factor messenger ribonucleic acid expression in ureteropelvic junction obstruction. J Urol 154:679-683

50. Cutroneo G, Arena S, Anastasi G, Cervellione RM, Grimaldi S, Di Mauro D, Speciale F, Arena F, Di Benedetto V, Favaloro A, Magno C (2011) Altered cytoskeletal structure of smooth muscle cells in ureteropelvic junction obstruction. J Urol 185:2314-2319

51. Esther CR Jr, Howard TE, Marino EM, Goddard JM, Capecchi MR, Bernstein KE (1996) Mice lacking angiotensin-converting enzyme have low blood pressure, renal pathology, and reduced male fertility. Lab Invest 74:953-965

52. Shindo T, Kurihara H, Kuno K, Yokoyama H, Wada T, Kurihara Y, Imai T, Wang Y, Ogata M, Nishimatsu H, Moriyama N, Oh-hashi Y, Morita H, Ishikawa T, Nagai R, Yazaki Y, Matsushima K (2000) ADAMTS-1: a metalloproteinasedisintegrin essential for normal growth, fertility, and organ morphology and function. J Clin Invest 105:1345-1352

53. Nagata M, Tanimoto K, Fukamizu A, Kon Y, Sugiyama F, Yagami K, Murakami K, Watanabe T (1996) Nephrogenesis and renovascular development in angiotensinogen-deficient mice. Lab Invest 75:745-753

54. McDill BW, Li SZ, Kovach PA, Ding L, Chen F (2006) Congenital progressive hydronephrosis ( $\mathrm{cph}$ ) is caused by an S256L mutation in aquaporin-2 that affects its phosphorylation and apical membrane accumulation. Proc Natl Acad Sci USA 103:6952-6957

55. Lu W, Quintero-Rivera F, Fan Y, Alkuraya FS, Donovan DJ, Xi Q, Turbe-Doan A, Li QG, Campbell CG, Shanske AL, Sherr EH, Ahmad A, Peters R, Rilliet B, Parvex P, Bassuk AG, Harris DJ, Ferguson H, Kelly C, Walsh CA, Gronostajski RM, Devriendt K, Higgins A, Ligon AH, Quade BJ, Morton CC, Gusella JF, Maas RL (2007) NFIA haploinsufficiency is associated with a CNS malformation syndrome and urinary tract defects. PLoS Genet 3:e80

56. Vivante A, Kleppa MJ, Schulz J, Kohl S, Sharma A, Chen J, Shril S, Hwang DY, Weiss AC, Kaminski MM, Shukrun R, Kemper MJ, Lehnhardt A, Beetz R, Sanna-Cherchi S, Verbitsky M, Gharavi AG, Stuart HM, Feather SA, Goodship JA, Goodship TH, Woolf AS, Westra SJ, Doody DP, Bauer SB, Lee RS, Adam RM, Lu W, Reutter HM, Kehinde EO, Mancini EJ, Lifton RP, Tasic V, Lienkamp SS, Juppner H, Kispert A, Hildebrandt F (2015) Mutations in TBX18 cause dominant urinary tract malformations via transcriptional dysregulation of ureter development. Am J Hum Genet 97:291-301

57. Jenkins D, Caubit X, Dimovski A, Matevska N, Lye CM, Cabuk F, Gucev Z, Tasic V, Fasano L, Woolf AS (2010) Analysis of TSHZ2 and TSHZ3 genes in congenital pelvi-ureteric junction obstruction. Nephrol Dial Transplant 25:54-60

58. Lye CM, Fasano L, Woolf AS (2010) Ureter myogenesis: putting Teashirt into context. J Am Soc Nephrol 21:24-30

59. Pope JC 4th, Showalter PR, Milam DF, Brock JW (1994) Intrapelvic pressure monitoring in the partially obstructed porcine kidney. Urology 44:565-571

60. Holden D, George NJ, Rickards D, Barnard RJ, O'Reilly PH (1984) Renal pelvic pressures in human chronic obstructive uropathy. Br J Urol 56:565-570

61. Kinn AC (1981) Pressure flow studies in hydronephrosis. Scand J Urol Nephrol 15:249-255

62. Chevalier RL (1984) Chronic partial ureteral obstruction in the neonatal guinea-pig. 2. Pressure-gradients affecting glomerularfiltration rate. Pediatr Res 18:1271-1277

63. Yoo KH, Norwood VF, el-Dahr SS, Yosipiv I, Chevalier RL (1997) Regulation of angiotensin II AT1 and AT2 receptors in neonatal ureteral obstruction. Am J Physiol 273:R503-509

64. el-Dahr SS, Gee J, Dipp S, Hanss BG, Vari RC, Chao J (1993) Upregulation of renin-angiotensin system and downregulation of kallikrein in obstructive nephropathy. Am J Physiol 264:F874 881

65. Durvasula RV, Petermann AT, Hiromura K, Blonski M, Pippin J, Mundel P, Pichler R, Griffin S, Couser WG, Shankland SJ (2004) Activation of a local tissue angiotensin system in podocytes by mechanical strain. Kidney Int 65:30-39

66. Taneda S, Hudkins KL, Topouzis S, Gilbertson DG, Ophascharoensuk V, Truong L, Johnson RJ, Alpers CE (2003) Obstructive uropathy in mice and humans: potential role for PDGF-D in the progression of tubulointerstitial injury. J Am Soc Nephrol 14:2544-2555

67. Manucha W, Kurban F, Mazzei L, Benardon ME, Bocanegra V, Tosi MR, Valles P (2011) eNOS/Hsp70 interaction on rosuvastatin cytoprotective effect in neonatal obstructive nephropathy. Eur J Pharmacol 650:487-495

68. Misseri R, Meldrum DR, Dinarello CA, Dagher P, Hile KL, Rink RC, Meldrum KK (2005) TNF-alpha mediates obstructioninduced renal tubular cell apoptosis and proapoptotic signaling. Am J Physiol Ren Physiol 288:F406-411

69. Norregaard R, Jensen BL, Li C, Wang W, Knepper MA, Nielsen S, Frokiaer J (2005) COX-2 inhibition prevents downregulation of key renal water and sodium transport proteins in response to bilateral ureteral obstruction. Am J Physiol Ren Physiol 289:F322-333

70. Nilsson L, Madsen K, Krag S, Frokiaer J, Jensen BL, Norregaard R (2015) Disruption of cyclooxygenase type 2 exacerbates apoptosis and renal damage during obstructive nephropathy. Am J Physiol Ren Physiol 309:F1035-1048

71. Chung KH, Chevalier RL (1996) Arrested development of the neonatal kidney following chronic ureteral obstruction. J Urol 155:1139-1144

72. Bartoli F, Gesualdo L, Paradies G, Caldarulo E, Infante B, Grandaliano G, Monno R, Leggio S, Salzillo F, Schena FP, Leggio A (2000) Renal expression of monocyte chemotactic protein-1 and epidermal growth factor in children with obstructive hydronephrosis. J Pediatr Surg 35:569-572

73. Yang Y, Hou Y, Wang CL, Ji SJ (2006) Renal expression of epidermal growth factor and transforming growth factor-betal in children with congenital hydronephrosis. Urology 67:817-821, discussion 821-812

74. Cai G, Zhang X, Hong Q, Shao F, Shang X, Fu B, Feng Z, Lin H, Wang J, Shi S, Yin Z, Chen X (2008) Tissue inhibitor of metalloproteinase-1 exacerbated renal interstitial fibrosis through enhancing inflammation. Nephrol Dial Transplant 23:1861-1875

75. Yeh YC, Wei WC, Wang YK, Lin SC, Sung JM, Tang MJ (2010) Transforming growth factor-\{beta 1 induces Smad3-dependent \{beta 1 integrin gene expression in epithelial-to-mesenchymal transition during chronic tubulointerstitial fibrosis. Am J Pathol 177:1743-1754

76. Hamzeh MT, Sridhara R, Alexander LD (2015) Cyclic stretchinduced TGF-betal and fibronectin expression is mediated by beta1-integrin through c-Src- and STAT3-dependent pathways in renal epithelial cells. Am J Physiol Ren Physiol 308:F425-436

77. Silverstein DM, Travis BR, Thornhill BA, Schurr JS, Kolls JK, Leung JC, Chevalier RL (2003) Altered expression of immune modulator and structural genes in neonatal unilateral ureteral obstruction. Kidney Int 64:25-35

78. Samarakoon R, Overstreet JM, Higgins SP, Higgins PJ (2012) TGF-beta1-SMAD/p53/USF2-PAI-1 transcriptional axis in ureteral obstruction-induced renal fibrosis. Cell Tissue Res 347:117-128

79. Garcia IM, Mazzei L, Benardon ME, Oliveros L, Cuello-Carrion FD, Gil Lorenzo A, Manucha W, Valles PG (2012) Caveolin-1eNOS/Hsp70 interactions mediate rosuvastatin antifibrotic effects in neonatal obstructive nephropathy. Nitric Oxide 27:95-105 
80. el-Dahr SS, Gomez RA, Gray MS, Peach MJ, Carey RM, Chevalier RL (1990) In situ localization of renin and its mRNA in neonatal ureteral obstruction. Am J Physiol 258:F854-862

81. Pimentel JL Jr, Martinez-Maldonado M, Wilcox JN, Wang S, Luo C (1993) Regulation of renin-angiotensin system in unilateral ureteral obstruction. Kidney Int 44:390-400

82. Ricardo SD, Franzoni DF, Roesener CD, Crisman JM, Diamond JR (2000) Angiotensinogen and AT(1) antisense inhibition of osteopontin translation in rat proximal tubular cells. Am J Physiol Ren Physiol 278:F708-716

83. Kaneto H, Morrissey J, Klahr S (1993) Increased expression of TGF-beta $1 \mathrm{mRNA}$ in the obstructed kidney of rats with unilateral ureteral ligation. Kidney Int 44:313-321

84. Morrissey JJ, Ishidoya S, McCracken R, Klahr S (1996) Nitric oxide generation ameliorates the tubulointerstitial fibrosis of obstructive nephropathy. J Am Soc Nephrol 7:2202-2212

85. Mazzei LJ, Garcia IM, Altamirano L, Docherty NG, Manucha W (2012) Rosuvastatin preserves renal structure following unilateral ureteric obstruction in the neonatal rat. Am J Nephrol 35:103-113

86. Han H, Zhu J, Wang Y, Zhu Z, Chen Y, Lu L, Jin W, Yan X, Zhang R (2017) Renal recruitment of B lymphocytes exacerbates tubulointerstitial fibrosis by promoting monocyte mobilization and infiltration after unilateral ureteral obstruction. J Pathol 241:80-90

87. Burt LE, Forbes MS, Thornhill BA, Kiley SC, Chevalier RL (2007) Renal vascular endothelial growth factor in neonatal obstructive nephropathy. I. Endogenous VEGF. Am J Physiol Ren Physiol 292:F158-167

88. Madsen MG (2013) Urinary biomarkers in hydronephrosis. Dan Med J 60:B4582

89. Moody TE, Vaughn ED Jr, Gillenwater JY (1975) Relationship between renal blood flow and ureteral pressure during 18 hours of total unilateral uretheral occlusion. Implications for changing sites of increased renal resistance. Invest Urol 13:246-251

90. Valles PG, Pascual L, Manucha W, Carrizo L, Ruttler M (2003) Role of endogenous nitric oxide in unilateral ureteropelvic junction obstruction in children. Kidney Int 63:1104-1115

91. Cachat F, Lange-Sperandio B, Chang AY, Kiley SC, Thornhill BA, Forbes MS, Chevalier RL (2003) Ureteral obstruction in neonatal mice elicits segment-specific tubular cell responses leading to nephron loss. Kidney Int 63:564-575

92. Topcu SO, Pedersen M, Norregaard R, Wang G, Knepper M, Djurhuus JC, Nielsen S, Jorgensen TM, Frokiaer J (2007) Candesartan prevents long-term impairment of renal function in response to neonatal partial unilateral ureteral obstruction. Am J Physiol Ren Physiol 292:F736-748

93. Koff SA (1985) Pressure volume relationships in human hydronephrosis. Urology 25:256-258

94. Yang Y, Zhou X, Gao H, Ji SJ, Wang C (2003) The expression of epidermal growth factor and transforming growth factor-betal in the stenotic tissue of congenital pelvi-ureteric junction obstruction in children. J Pediatr Surg 38:1656-1660

95. Knerr I, Nyul Z, Miller J, Rosch W, Dotsch J, Repp R, Weidner W, Rascher W (2001) Increased endothelin-1 and decreased adrenomedullin gene expression in the stenotic tissue of congenital pelvi-ureteric junction obstruction in children. BJU Int 87: $667-671$

96. Seremetis GM, Maizels M (1996) TGF-beta mRNA expression in the renal pelvis after experimental and clinical ureteropelvic junction obstruction. J Urol 156:261-266

97. Klahr S, Ishidoya S, Morrissey J (1995) Role of angiotensin II in the tubulointerstitial fibrosis of obstructive nephropathy. Am J Kidney Dis 26:141-146

98. Picard N, Baum O, Vogetseder A, Kaissling B, Le Hir M (2008) Origin of renal myofibroblasts in the model of unilateral ureter obstruction in the rat. Histochem Cell Biol 130:141-155
99. Hinz B, Celetta G, Tomasek JJ, Gabbiani G, Chaponnier C (2001) Alpha-smooth muscle actin expression upregulates fibroblast contractile activity. Mol Biol Cell 12:2730-2741

100. Strutz F, Zeisberg M (2006) Renal fibroblasts and myofibroblasts in chronic kidney disease. J Am Soc Nephrol 17:2992-2998

101. Zeisberg M, Strutz F, Muller GA (2001) Renal fibrosis: an update. Curr Opin Nephrol Hypertens 10:315-320

102. Han SW, Lee SE, Kim JH, Jeong HJ, Rha KH, Choi SK (1998) Does delayed operation for pediatric ureteropelvic junction obstruction cause histopathological changes? J Urol 160:984-988

103. Border WA, Noble NA (1998) Interactions of transforming growth factor-beta and angiotensin II in renal fibrosis. Hypertension 31: 181-188

104. Fern RJ, Yesko CM, Thornhill BA, Kim HS, Smithies O, Chevalier RL (1999) Reduced angiotensinogen expression attenuates renal interstitial fibrosis in obstructive nephropathy in mice. J Clin Invest 103:39-46

105. Ishidoya S, Morrissey J, McCracken R, Reyes A, Klahr S (1995) Angiotensin II receptor antagonist ameliorates renal tubulointerstitial fibrosis caused by unilateral ureteral obstruction. Kidney Int 47:1285-1294

106. Guo G, Morrissey J, McCracken R, Tolley T, Liapis H, Klahr S (2001) Contributions of angiotensin II and tumor necrosis factoralpha to the development of renal fibrosis. Am J Physiol Ren Physiol 280:F777-785

107. Fukuda K, Yoshitomi K, Yanagida T, Tokumoto M, Hirakata H (2001) Quantification of TGF-beta1 mRNA along rat nephron in obstructive nephropathy. Am J Physiol Ren Physiol 281:F513-521

108. Klahr S, Morrissey J (1998) Angiotensin II and gene expression in the kidney. Am J Kidney Dis 31:171-176

109. Chevalier RL, Forbes MS, Galarreta CI, Thornhill BA (2014) Responses of proximal tubular cells to injury in congenital renal disease: fight or flight. Pediatr Nephrol 29:537-541

110. Miyajima A, Chen J, Lawrence C, Ledbetter S, Soslow RA, Stern J, Jha S, Pigato J, Lemer ML, Poppas DP, Vaughan ED, Felsen D (2000) Antibody to transforming growth factor-beta ameliorates tubular apoptosis in unilateral ureteral obstruction. Kidney Int 58: 2301-2313

111. Manucha W, Oliveros L, Carrizo L, Seltzer A, Valles P (2004) Losartan modulation on NOS isoforms and COX-2 expression in early renal fibrogenesis in unilateral obstruction. Kidney Int 65: 2091-2107

112. Jensen AM, Li C, Praetorius HA, Norregaard R, Frische S, Knepper MA, Nielsen S, Frokiaer J (2006) Angiotensin II mediates downregulation of aquaporin water channels and key renal sodium transporters in response to urinary tract obstruction. Am J Physiol Ren Physiol 291:F1021-1032

113. Kellner D, Chen J, Richardson I, Seshan SV, El Chaar M, Vaughan ED Jr, Poppas D, Felsen D (2006) Angiotensin receptor blockade decreases fibrosis and fibroblast expression in a rat model of unilateral ureteral obstruction. J Urol 176:806-812

114. Derynck R, Zhang YE (2003) Smad-dependent and Smadindependent pathways in TGF-beta family signalling. Nature 425:577-584

115. Lan HY, Mu W, Tomita N, Huang XR, Li JH, Zhu HJ, Morishita R, Johnson RJ (2003) Inhibition of renal fibrosis by gene transfer of inducible Smad7 using ultrasound-microbubble system in rat UUO model. J Am Soc Nephrol 14:1535-1548

116. Meng XM, Huang XR, Xiao J, Chen HY, Zhong X, Chung AC, Lan HY (2012) Diverse roles of TGF-beta receptor II in renal fibrosis and inflammation in vivo and in vitro. J Pathol 227:175-188

117. Galarreta CI, Thornhill BA, Forbes MS, Simpkins LN, Kim DK, Chevalier RL (2013) Transforming growth factor-betal receptor inhibition preserves glomerulotubular integrity during ureteral obstruction in adults but worsens injury in neonatal mice. Am J Physiol Ren Physiol 304:F481-490 
118. Sato M, Muragaki Y, Saika S, Roberts AB, Ooshima A (2003) Targeted disruption of TGF-beta1/Smad3 signaling protects against renal tubulointerstitial fibrosis induced by unilateral ureteral obstruction. J Clin Invest 112:1486-1494

119. Yang SP, Woolf AS, Quinn F, Winyard PJ (2001) Deregulation of renal transforming growth factor-betal after experimental shortterm ureteric obstruction in fetal sheep. Am J Pathol 159:109-117

120. Chung KH, Gomez RA, Chevalier RL (1995) Regulation of renal growth factors and clusterin by AT1 receptors during neonatal ureteral obstruction. Am J Physiol 268:F1117-1123

121. Pimentel JL, Sundell CL, Wang SS, Kopp JB, Montero A, Martinezmaldonado M (1995) Role of angiotensin-li in the expression and regulation of transforming growth-factor-beta in obstructive nephropathy. Kidney Int 48:1233-1246

122. Murer L, Benetti E, Centi S, Della Vella M, Artifoni L, Capizzi A, Zucchetta P, Del Prete D, Carasi C, Montini G, Rigamonti W, Zaccello G (2006) Clinical and molecular markers of chronic interstitial nephropathy in congenital unilateral ureteropelvic junction obstruction. J Urol 176:2668-2673

123. Forbes MS, Thornhill BA, Park MH, Chevalier RL (2007) Lack of endothelial nitric-oxide synthase leads to progressive focal renal injury. Am J Pathol 170:87-99

124. Sun D, Wang Y, Liu C, Zhou X, Li X, Xiao A (2012) Effects of nitric oxide on renal interstitial fibrosis in rats with unilateral ureteral obstruction. Life Sci 90:900-909

125. Chang B, Mathew R, Palmer LS, Valderrama E, Trachtman H (2002) Nitric oxide in obstructive uropathy: role of endothelial nitric oxide synthase. J Urol 168:1801-1804

126. Valles PG, Manucha W, Carrizo L, Vega Perugorria J, Seltzer A, Ruete C (2007) Renal caveolin-1 expression in children with unilateral ureteropelvic junction obstruction. Pediatr Nephrol 22:237-248

127. Nasu T, Kinomura M, Tanabe K, Yamasaki H, Htay SL, Saito D, Hinamoto N, Watatani H, Ujike H, Suzuki Y, Sugaya T, Sugiyama H, Sakai Y, Matsumoto K, Maeshima Y, Makino H (2012) Sustained-release prostacyclin analog ONO-1301 ameliorates tubulointerstitial alterations in a mouse obstructive nephropathy model. Am J Physiol Ren Physiol 302:F1616-1629

128. Miyajima A, Chen J, Poppas DP, Vaughan ED Jr, Felsen D (2001) Role of nitric oxide in renal tubular apoptosis of unilateral ureteral obstruction. Kidney Int 59:1290-1303

129. Mazzei L, Garcia IM, Cacciamani V, Benardon ME, Manucha W (2010) WT-1 mRNA expression is modulated by nitric oxide availability and Hsp70 interaction after neonatal unilateral ureteral obstruction. Biocell 34:121-132

130. Jensen AM, Bae EH, Fenton RA, Norregaard R, Nielsen S, Kim SW, Frokiaer J (2009) Angiotensin II regulates V2 receptor and pAQP2 during ureteral obstruction. Am J Physiol Ren Physiol 296:F127-134

131. Li C, Wang W, Kwon TH, Knepper MA, Nielsen S, Frokiaer J (2003) Altered expression of major renal $\mathrm{Na}$ transporters in rats with unilateral ureteral obstruction. Am J Physiol Ren Physiol 284:F155-166

132. Li C, Wang W, Kwon TH, Knepper MA, Nielsen S, Frokiaer J (2003) Altered expression of major renal $\mathrm{Na}$ transporters in rats with bilateral ureteral obstruction and release of obstruction. Am J Physiol Ren Physiol 285:F889-901

133. Li C, Klein JD, Wang W, Knepper MA, Nielsen S, Sands JM, Frokiaer J (2004) Altered expression of urea transporters in response to ureteral obstruction. Am J Physiol Ren Physiol 286:F1154-1162

134. Li C, Wang W, Knepper MA, Nielsen S, Frokiaer J (2003) Downregulation of renal aquaporins in response to unilateral ureteral obstruction. Am J Physiol Ren Physiol 284:F1066-1079

135. Shi Y, Li C, Thomsen K, Jorgensen TM, Knepper MA, Nielsen S, Djurhuus JC, Frokiaer J (2004) Neonatal ureteral obstruction alters expression of renal sodium transporters and aquaporin water channels. Kidney Int 66:203-215

136. Frokiaer J, Christensen BM, Marples D, Djurhuus JC, Jensen UB, Knepper MA, Nielsen S (1997) Downregulation of aquaporin-2 parallels changes in renal water excretion in unilateral ureteral obstruction. Am J Physiol 273:F213-223

137. Chen YC, Cadnapaphornchai MA, Schrier RW (2005) Clinical update on renal aquaporins. Biol Cell 97:357-371

138. Rubenwolf PC, Georgopoulos NT, Clements LA, Feather S, Holland P, Thomas DF, Southgate J (2009) Expression and localisation of aquaporin water channels in human urothelium in situ and in vitro. Eur Urol 56:1013-1023

139. Spector DA, Wade JB, Dillow R, Steplock DA, Weinman EJ (2002) Expression, localization, and regulation of aquaporin-1 to -3 in rat urothelia. Am J Physiol Ren Physiol 282:F1034-1042

140. Agre P, King LS, Yasui M, Guggino WB, Ottersen OP, Fujiyoshi Y, Engel A, Nielsen S (2002) Aquaporin water channels - from atomic structure to clinical medicine. J Physiol 542:3-16

141. Wen JG, Li ZZ, Zhang H, Wang Y, Wang G, Wang Q, Nielsen S, Djurhuus JC, Frokiaer J (2009) Expression of renal aquaporins is down-regulated in children with congenital hydronephrosis. Scand J Urol Nephrol 43:486-493

142. Frokiaer J, Marples D, Knepper MA, Nielsen S (1996) Bilateral ureteral obstruction downregulates expression of vasopressin-sensitive AQP-2 water channel in rat kidney. Am J Physiol 270:F657-668

143. Li C, Wang W, Kwon TH, Isikay L, Wen JG, Marples D, Djurhuus JC, Stockwell A, Knepper MA, Nielsen S, Frokiaer J (2001) Downregulation of AQP1, -2 , and -3 after ureteral obstruction is associated with a long-term urine-concentrating defect. Am J Physiol Ren Physiol 281:F163-171

144. Ishidoya S, Morrissey J, McCracken R, Klahr S (1996) Delayed treatment with enalapril halts tubulointerstitial fibrosis in rats with obstructive nephropathy. Kidney Int 49:1110-1119

145. Kaneto H, Morrissey J, McCracken R, Reyes A, Klahr S (1994) Enalapril reduces collagen type IV synthesis and expansion of the interstitium in the obstructed rat kidney. Kidney Int 45:1637-1647

146. Klahr S, Morrissey J (2002) Comparative effects of ACE inhibition and angiotensin II receptor blockade in the prevention of renal damage. Kidney Int Suppl 82:S23-26

147. Chen CO, Park MH, Forbes MS, Thornhill BA, Kiley SC, Yoo $\mathrm{KH}$, Chevalier RL (2007) Angiotensin-converting enzyme inhibition aggravates renal interstitial injury resulting from partial unilateral ureteral obstruction in the neonatal rat. Am J Physiol Ren Physiol 292:F946-955

148. Coleman CM, Minor JJ, Burt LE, Thornhill BA, Forbes MS, Chevalier RL (2007) Angiotensin AT1-receptor inhibition exacerbates renal injury resulting from partial unilateral ureteral obstruction in the neonatal rat. Am J Physiol Ren Physiol 293:F262-268

149. Webb NJ, Shahinfar S, Wells TG, Massaad R, Gleim GW, Santoro EP, Sisk CM, Lam C (2012) Losartan and enalapril are comparable in reducing proteinuria in children. Kidney Int 82:819-826

150. ItalKid Project, Ardissino G, Vigano S, Testa S, Dacco V, Paglialonga F, Leoni A, Belingheri M, Avolio L, Ciofani A, Claris-Appiani A, Cusi D, Edefonti A, Ammenti A, Cecconi M, Fede C, Ghio L, La Manna A, Maringhini S, Papalia T, Pela I, Pisanello L, Ratsch IM (2007) No clear evidence of ACEi efficacy on the progression of chronic kidney disease in children with hypodysplastic nephropathy-report from the ItalKid Project database. Nephrol Dial Transplant 22:2525-2530

151. Hari P, Sahu J, Sinha A, Pandey RM, Bal CS, Bagga A (2013) Effect of enalapril on glomerular filtration rate and proteinuria in children with chronic kidney disease: a randomized controlled trial. Indian Pediatr 50:923-928

152. Moriyama T, Kawada N, Nagatoya K, Takeji M, Horio M, Ando A, Imai E, Hori M (2001) Fluvastatin suppresses oxidative stress and fibrosis in the interstitium of mouse kidneys with unilateral ureteral obstruction. Kidney Int 59:2095-2103

153. Mizuguchi Y, Miyajima A, Kosaka T, Asano T, Asano T, Hayakawa M (2004) Atorvastatin ameliorates renal tissue damage in unilateral ureteral obstruction. J Urol 172:2456-2459 
154. Rodriguez-Pena AB, Fuentes-Calvo I, Docherty NG, Arevalo M, Grande MT, Eleno N, Perez-Barriocanal F, Lopez-Novoa JM (2014) Effect of angiotensin II and small GTPase Ras signaling pathway inhibition on early renal changes in a murine model of obstructive nephropathy. Biomed Res Int 2014:124902

155. Jasinska M, Owczarek J, Orszulak-Michalak D (2007) Statins: a new insight into their mechanisms of action and consequent pleiotropic effects. Pharmacol Rep 59:483-499

156. Kamdar C, Chou SY, Mooppan UM, Kim H, Gulmi FA (2010) Atorvastatin protects renal function in the rat with acute unilateral ureteral obstruction. Urology 75:853-857

157. Danilovic A, Lopes RI, Sanches TR, Shimizu MH, Oshiro FM, Andrade L, Denes FT, Seguro AC (2012) Atorvastatin prevents the downregulation of aquaporin-2 receptor after bilateral ureteral obstruction and protects renal function in a rat model. Urology 80(485):e415-420

158. Ramkumar S, Raghunath A, Raghunath S (2016) Statin therapy: review of safety and potential side effects. Acta Cardiol Sin 32:631-639

159. Kusters DM, Avis HJ, de Groot E, Wijburg FA, Kastelein JJ, Wiegman A, Hutten BA (2014) Ten-year follow-up after initiation of statin therapy in children with familial hypercholesterolemia. JAMA 312:1055-1057

160. Moon JA, Kim HT, Cho IS, Sheen YY, Kim DK (2006) IN-1130, a novel transforming growth factor-beta type I receptor kinase (ALK5) inhibitor, suppresses renal fibrosis in obstructive nephropathy. Kidney Int 70:1234-1243

161. Morris JC, Shapiro GI, Tan AR, Lawrence DP, Olencki TE, Dezube BJ, Hsu FJ, Reiss M, Berzofsky JA (2008) Phase I/II study of GC1008: A human anti-transforming growth factorbeta (TGF $\beta$ ) monoclonal antibody in patients with advanced malignant melanoma or renal cell carcinoma. J Clin Oncol 26[Suppl]: abstr 9028

162. Kamata M, Hosono K, Fujita T, Kamata K, Majima M (2015) Role of cyclooxygenase- 2 in the development of interstitial fibrosis in kidneys following unilateral ureteral obstruction in mice. Biomed Pharmacother 70:174-180

163. Pediatric Rheumatology Collaborative Study Group, Sobel RE, Lovell DJ, Brunner HI, Weiss JE, Morris PW, Gottlieb BS, Chalom EC, Jung LK, Onel KB, Petiniot L, Goldsmith DP, Nanda K, Shishov M, Abramsky S, Young JP, Giannini EH (2014) Safety of celecoxib and nonselective nonsteroidal antiinflammatory drugs in juvenile idiopathic arthritis: results of the Phase 4 registry. Pediatr Rheumatol Online J 12:29

164. Shiva S (2013) Nitrite: a physiological store of nitric oxide and modulator of mitochondrial function. Redox Biol 1:40-44

165. Tripatara P, Patel NS, Webb A, Rathod K, Lecomte FM, Mazzon E, Cuzzocrea S, Yaqoob MM, Ahluwalia A, Thiemermann C (2007) Nitrite-derived nitric oxide protects the rat kidney against ischemia/reperfusion injury in vivo: role for xanthine oxidoreductase. J Am Soc Nephrol 18:570-580

166. Gilchrist M, Winyard PG, Benjamin N (2010) Dietary nitrategood or bad? Nitric Oxide 22:104-109

167. Yuan Y, Zhang F, Wu J, Shao C, Gao Y (2015) Urinary candidate biomarker discovery in a rat unilateral ureteral obstruction model. Sci Rep 5:9314

168. Taha MA, Shokeir AA, Osman HG, Abd El-Aziz Ael A, Farahat SE (2007) Obstructed versus dilated nonobstructed kidneys in children with congenital ureteropelvic junction narrowing: role of urinary tubular enzymes. J Urol 178:640-646

169. Taranta-Janusz K, Wasilewska A, Debek W, Filonowicz R, Michaluk-Skutnik J (2013) Urinary angiotensinogen as a novel marker of obstructive nephropathy in children. Acta Paediatr 102: e429-433

170. Bartoli F, Penza R, Aceto G, Niglio F, D'Addato O, Pastore V, Campanella V, Magaldi S, Lasalandra C, Di Bitonto G, Gesualdo
L (2011) Urinary epidermal growth factor, monocyte chemotactic protein-1, and beta2-microglobulin in children with ureteropelvic junction obstruction. J Pediatr Surg 46:530-536

171. Madsen MG, Norregaard R, Palmfeldt J, Olsen LH, Frokiaer J, Jorgensen TM (2012) Urinary NGAL, cystatin C, beta2-microglobulin, and osteopontin significance in hydronephrotic children. Pediatr Nephrol 27:2099-2106

172. Atar A, Oktar T, Kucukgergin C, Kalelioglu I, Seckin S, Ander H, Ziylan O, Kadioglu TC (2015) The roles of serum and urinary carbohydrate antigen 19-9 in the management of patients with antenatal hydronephrosis. J Pediatr Urol 11(133):e1-5

173. Kajbafzadeh AM, Elmi A, Talab SS, Emami H, Esfahani SA, Saeedi P (2010) Urinary and serum carbohydrate antigen 19-9 as a biomarker in ureteropelvic junction obstruction in children. J Urol 183:2353-2360

174. Grandaliano G, Gesualdo L, Bartoli F, Ranieri E, Monno R, Leggio A, Paradies G, Caldarulo E, Infante B, Schena FP (2000) MCP-1 and EGF renal expression and urine excretion in human congenital obstructive nephropathy. Kidney Int 58:182-192

175. Madsen MG, Norregaard R, Palmfeldt J, Olsen LH, Frokiaer J, Jorgensen TM (2013) Epidermal growth factor and monocyte chemotactic peptide-1: potential biomarkers of urinary tract obstruction in children with hydronephrosis. J Pediatr Urol 9:838-845

176. Taha MA, Shokeir AA, Osman HG, Abd El-Aziz Ael A, Farahat SE (2007) Pelvi-ureteric junction obstruction in children: the role of urinary transforming growth factor-beta and epidermal growth factor. BJU Int 99:899-903

177. Taha MA, Shokeir AA, Osman HG, Abd el-Aziz Ael A, Farahat SE (2007) Diagnosis of ureteropelvic junction obstruction in children: role of endothelin-1 in voided urine. Urology 69:560-564, discussion 564-565

178. Li Z, Liu X, Liu S, Gu C, Tian F, Wen J (2012) Urinary heme oxygenase-1 in children with congenital hydronephrosis due to ureteropelvic junction obstruction. Biomarkers 17:471-476

179. Wasilewska A, Taranta-Janusz K, Debek W, Zoch-Zwierz W, Kuroczycka-Saniutycz E (2011) KIM-1 and NGAL: new markers of obstructive nephropathy. Pediatr Nephrol 26:579-586

180. Taranta-Janusz K, Wasilewska A, Debek W, Waszkiewicz-Stojda M (2012) Urinary cytokine profiles in unilateral congenital hydronephrosis. Pediatr Nephrol 27:2107-2113

181. Cost NG, Noh PH, Devarajan P, Ivancic V, Reddy PP, Minevich E, Bennett M, Haffner C, Schulte M, DeFoor WR Jr (2013) Urinary NGAL levels correlate with differential renal function in patients with ureteropelvic junction obstruction undergoing pyeloplasty. $\mathrm{J}$ Urol 190[4 Supp]:1462-1467

182. Almodhen F, Loutochin O, Capolicchio JP, Jednak R, El-Sherbiny M (2009) The role of bladder urine transforming growth factorbeta1 concentrations in diagnosis and management of unilateral prenatal hydronephrosis. J Urol 182:292-298, discussion 298

183. Madsen MG, Norregaard R, Frokiaer J, Jorgensen TM (2011) Urinary biomarkers in prenatally diagnosed unilateral hydronephrosis. J Pediatr Urol 7:105-112

184. Papachristou F, Pavlaki A, Printza N (2014) Urinary and serum biomarkers in ureteropelvic junction obstruction: a systematic review. Biomarkers 19:531-540

185. Decramer S, Wittke S, Mischak H, Zurbig P, Walden M, Bouissou F, Bascands JL, Schanstra JP (2006) Predicting the clinical outcome of congenital unilateral ureteropelvic junction obstruction in newborn by urinary proteome analysis. Nat Med 12:398-400

186. Drube J, Zurbig P, Schiffer E, Lau E, Ure B, Gluer S, Kirschstein M, Pape L, Decramer S, Bascands JL, Schanstra JP, Mischak H, Ehrich JH (2010) Urinary proteome analysis identifies infants but not older children requiring pyeloplasty. Pediatr Nephrol 25:1673-1678 